\title{
Mapping the Coastal Upwelling East of Taiwan Using Geostationary Satellite Data
}

\author{
Zhi Huang ${ }^{1}$, Jianyu $\mathrm{Hu}^{1,2, *(\mathbb{D})}$ and Weian Shi ${ }^{1}$ (D) \\ 1 State Key Laboratory of Marine Environmental Science, College of Ocean and Earth Sciences, \\ Xiamen University, Xiamen 361102, China; zhihuang77@hotmail.com (Z.H.); \\ 22320190154048@stu.xmu.edu.cn (W.S.) \\ 2 Southern Marine Science and Engineering Guangdong Laboratory (Zhuhai), Zhuhai 519000, China \\ * Correspondence: hujy@xmu.edu.cn
}

Citation: Huang, Z.; Hu, J.; Shi, W. Mapping the Coastal Upwelling East of Taiwan Using Geostationary Satellite Data. Remote Sens. 2021, 13, 170. https://doi.org/10.3390/rs13020170

Received: 2 December 2020

Accepted: 4 January 2021

Published: 6 January 2021

Publisher's Note: MDPI stays neutral with regard to jurisdictional clai$\mathrm{ms}$ in published maps and institutional affiliations.

Copyright: (C) 2021 by the authors. Licensee MDPI, Basel, Switzerland. This article is an open access article distributed under the terms and conditions of the Creative Commons Attribution (CC BY) license (https:// creativecommons.org/licenses/by/ $4.0 /)$.

\begin{abstract}
Coastal upwelling is important for coastal ecosystems and the blue economy because of its large productivity and large potential for catching fish. However, coastal upwelling along the Taiwan east coast has received little attention from the research community. This study used five-year daily Himawari-8 geostationary satellite sea surface temperature data to map the coastal upwelling east of Taiwan during the summer monsoon season. We applied a semi-automatic image process technique based on the topographic position index for the quantitative upwelling mapping. The results show clear evidence of seasonal coastal upwelling along the entire Taiwan east coast, mainly under the influence of upwelling-favorable southwesterly/southerly winds. There are three broad upwelling centers along the Taiwan east coast: north, central, and south. The upwelling around the northern center has the longest upwelling season, lasting from May to September. The upwelling extents are larger between June and August during the height of the summer monsoon.
\end{abstract}

Keywords: coastal upwelling; Himawari-8; sea surface temperature; Taiwan; topographic position index; upwelling index; mapping

\section{Introduction}

Coastal upwelling is important for coastal ecosystems and the blue economy, because of its elevated productivity and large potential for fish catch resulted from the uplifting of nutrient-rich water towards the sea surface [1,2]. Major coastal upwelling systems are found around the world [1-6]. There are numerous upwelling hotspots in these major coastal upwelling systems, a number of which are known to occur in the China seas [3]. In their comprehensive review, ref. [3] identified 12 major upwelling regions in the China seas. Four of these upwelling regions are located in the Taiwan Strait (Southwestern Taiwan Strait, Northwestern Taiwan Strait, Taiwan Bank, and Penghu Islands), and one is located offshore Northeast of Taiwan.

Numerous studies have been focused on the offshore upwelling to the Northeast of Taiwan, which is associated with a cyclonic cold dome [7-10]. Little literature, however, has indicated the existence of coastal upwelling along the Taiwan east coast.

Taiwan Island is under the subtropical monsoon regime. Hence, the southwesterly/southerly (northeasterly/northerly) winds dominate in summer (winter). Although the southwesterly/southerly summer monsoon (June-August) is usually weaker than the northeasterly/northerly winter monsoon [11], the upwelling-favorable winds are still expected to induce upwelling along the Taiwan east coast, according to the classical Ekman transport theory. A similar mechanism has indeed been identified for the coastal upwelling in the northwestern and southwestern Taiwan Strait along the Fujian coast [3,12,13]. In addition, the Taiwan east coast is also influenced by the poleward flowing Kuroshio Current. However, the Kuroshio Current migrates offshore in summer [9,14]; and as a result, 
its potential influence on the summer upwelling along the Taiwan east coast is unclear and could be limited or secondary.

This study aimed to investigate the wind-driven coastal upwelling along the east coast of Taiwan using Himawari-8 sea surface temperature (SST) data. The objectives of this study include, (1) to identify significant upwelling-favorable wind events in the summers of recent several years; (2) to map the extent of the coastal upwelling using daily Himawari-8 SST data and examine its relationship with the wind events; and (3) to quantitatively investigate the characteristics of the coastal upwelling.

Remotely sensed SST data have often been used to detect and map upwelling that exhibits local SST anomaly on the sea surface $[4,9,10,15,16]$. A coastal upwelling event often develops rapidly after a distinct onset and lasts from several days to some weeks, depending on the local condition. The monthly-composited Moderate Resolution Imaging Spectroradiometer (MODIS) SST data used in [4] does not have an adequate temporal resolution to capture the development of an upwelling event. The daily MODIS and Advanced Very High Resolution Radiometer (AVHRR) SST data used in $[15,16]$ are also not suitable for daily upwelling mapping because they often suffer incomplete spatial coverage due to clouds and much lower observation frequency (e.g., twice daily). The Himawari-8 SST data, on the other hand, offer unique advantages in the study of the daily development of upwelling events because of its reliability and high spatial $(\sim 2 \mathrm{~km})$ and temporal resolutions $(10 \mathrm{~min})[17,18]$. The merits of the Himawari-8 SST data have been recognized in the two recent upwelling studies [9,10], which used Himawari-8 SST data to investigate the upwelling off Northeastern Taiwan. In [9], the upwelling was only visually examined without attempting to explicitly map the upwelling extent; while in [10], a relatively complex gradient-based edge detection algorithm was used to map the upwelling. In this study, however, we used a scale-independent and relatively straightforward semiautomatic method developed and proved reliable in a recent upwelling study [4]. The near-real-time Himawari-8 SST data and the mapping technique developed in this study have the potential to be operationalized and thus provide a valuable monitoring tool for coastal upwelling.

\section{Data and Methods}

\subsection{Study Area, Study Period, and Its Climate}

The climate of Taiwan Island is predominantly affected by the East Asian monsoon. Hence, the weak southwesterly/southerly (strong northeasterly/northerly) winds usually prevail in summer (winter) [11]. The waters surrounding Taiwan Island are influenced by three major ocean currents [19]. Taiwan's east coast is mainly affected by the northwardflowing Kuroshio Current; while the Taiwan Strait is also affected by the intrusion of the Kuroshio Current, in addition to the southward flowing China Coastal Current in winter and the northward-flowing extension of the South China Sea Warm Current (or the Taiwan Strait Warm Current) throughout the year. In general, the SST is lower in the Taiwan Strait than that in the east of Taiwan, with an annual mean of $>26^{\circ} \mathrm{C}$ [20]. The salinity ranges 31-34 psu and has a relatively large spatial-temporal variability in the Taiwan Strait; while, it remains relatively stable east of Taiwan [20].

In this study, the study area was located to the east of Taiwan, with two sub-areas: one $20 \mathrm{~km}$ buffer and the other 20-70 km buffer from the east coast (Figure 1). The coastal upwelling is defined as the upwelling area mainly within the $20 \mathrm{~km}$ buffer, but may extend to the 20-70 km buffer. The study period is from May to September each year, between 2015 and 2019. Among these months, June to August is the main summer monsoon season; while, May and September are the transition period. 


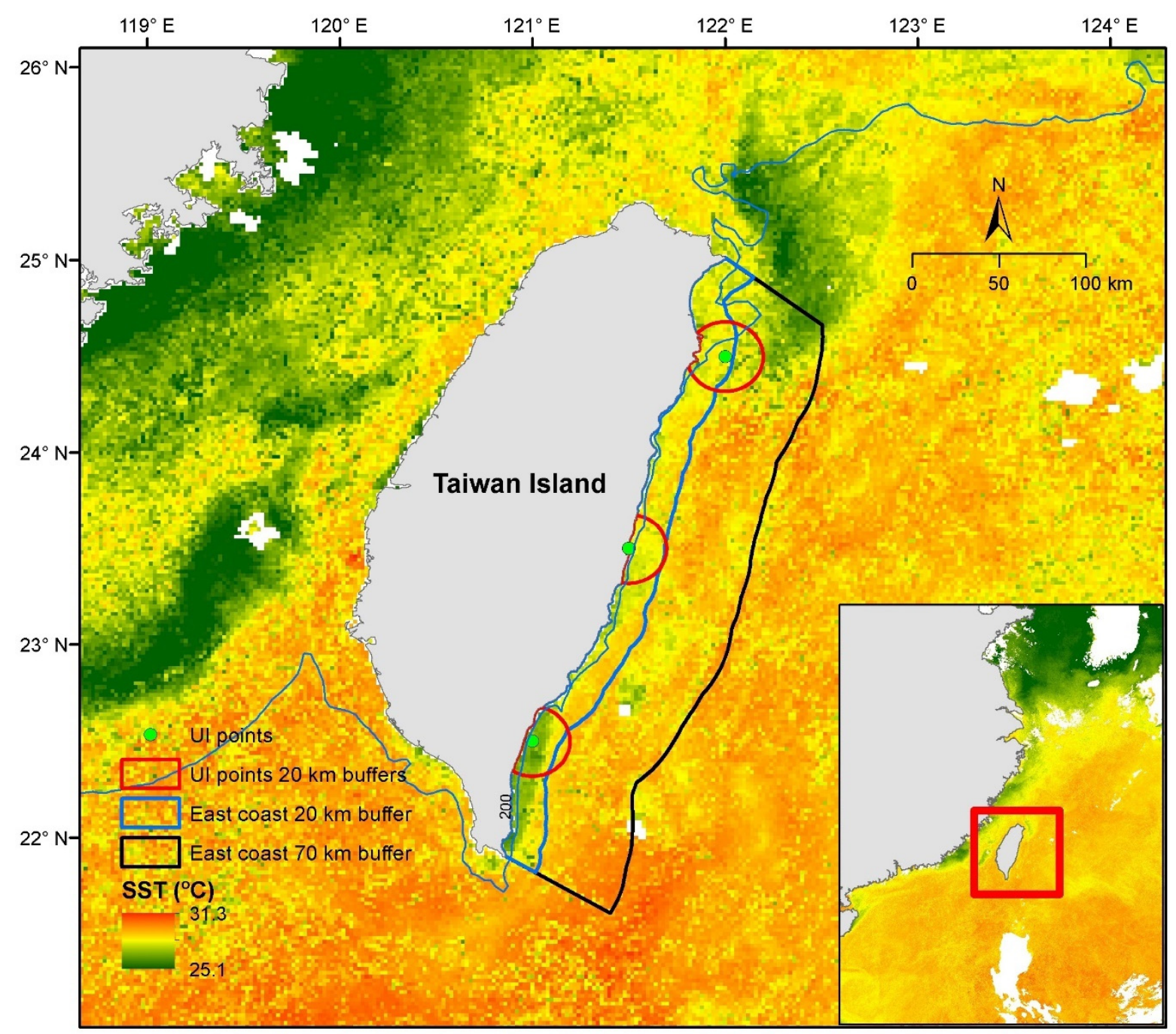

Figure 1. The study area is the coastal area of eastern Taiwan Island; the thick blue and black lines indicate the $20 \mathrm{~km}$ and $70 \mathrm{~km}$ buffers from the east coast of Taiwan; the green dots indicate the locations where the upwelling index (UI) was calculated using the CFS wind data; the red lines indicate the $20 \mathrm{~km}$ buffer around the UI points; the thin blue line is the $200 \mathrm{~m}$ isobath representing the approximate boundary of the continental shelf. The background image is the H-8 SST image on 19 July 2016.

\subsection{Wind Data, Upwelling Index and Significant Upwelling-favorable Wind Events}

We used wind data to calculate an upwelling index (UI). The Ekman-based upwelling index has been widely used for upwelling studies $[2,4-6]$. The wind data were obtained from CFSv2 (Climate Forecast System version 2) data of NCEP (National Center for Environmental Prediction) [21]. Based on ground observation, satellite data assimilation and reanalysis, the Climate Forecast System (CFS) is a global high-resolution coupling system of atmospheric-sea-land. The wind data have a spatial resolution of $0.5^{\circ} \times 0.5^{\circ}$ and a temporal resolution of $6 \mathrm{~h}$.

The daily composited wind data were first calculated from the 6-hourly data. The daily UI (in $\mathrm{m}^{2} \mathrm{~s}^{-1}$ ) was then calculated using the following equations:

$$
\begin{gathered}
\mathrm{UI}=\frac{\tau}{f \rho_{w}} \cos (\alpha-\beta) \\
\tau=\rho_{a} C_{d} V^{2}
\end{gathered}
$$




$$
\begin{gathered}
f=2 \omega \sin (\varphi) \\
C_{d}=(0.8+0.065 V) \times 0.001
\end{gathered}
$$

where $\tau$ is the wind stress, $\rho_{a}$ is the air density $\left(1.22 \mathrm{~kg} \mathrm{~m}^{-3}\right), \rho_{w}$ is the seawater density $\left(1026 \mathrm{~kg} \mathrm{~m}^{-3}\right), C_{d}$ is the drag coefficient calculated using the empirical equation of [22], $f$ is the Coriolis parameter $\left(\mathrm{s}^{-1}\right), \alpha$ is the wind direction, $\beta$ is the general shoreline orientation, $\omega$ is the rotation rate of the Earth $\left(7.2921 \times 10^{-5} \mathrm{rads}^{-1}\right), \varphi$ is the latitude, and $V$ is the wind speed (in $\mathrm{m} \mathrm{s}^{-1}$ ).

We calculated UI at three coastal locations (Figure 1), representing the northern, central and southern sections of the Taiwan east coast. The $\beta$ values were set at $18^{\circ}, 15^{\circ}$, and $20^{\circ}$ from the northern aspect, for the northern, central, and southern locations, respectively. The significant upwelling-favorable wind events from May to September each year were then identified using the following criteria:

1. $\geq 5$ days of positive UI, satisfying one of the following conditions:

a. $\quad \geq 5$ days of consecutive positive UI;

b. $\quad \geq 3$ days of consecutive positive UI, followed by 1 day of negative UI, then followed by $\geq 2$ days of consecutive positive UI;

c. $\geq 4$ days of consecutive positive UI, followed by 2 days of negative UI, then followed by $\geq 3$ days of consecutive positive UI;

d. $\geq 5$ days of consecutive positive UI, followed by 3 days of negative UI, then followed by $\geq 5$ days of consecutive positive UI.

2. The cumulative UI for the first five days $\geq 2.0 \mathrm{~m}^{2} \mathrm{~s}^{-1}$

These criteria consider both the duration and intensity in the definition of a significant upwelling-favorable wind event. Note that a significant wind event is allowed to expand a few days into April or October to maintain the integrity of the event.

\subsection{Himawari-8 SST Data and Upwelling Mapping}

The Himawari-8 meteorological satellite was launched by the Japan Meteorological Agency (JMA) in October 2014 [17]. The Himawari-8 is a new generation geostationary satellite carrying an Advanced Himawari Imager (AHI), capable of providing geophysical data at a spatial resolution of $\sim 2 \mathrm{~km}$ and a temporal resolution of 10-min full-disk frequency [17]. The Himawari-8 (H-8) SST data used in this study were processed by the Japan Aerospace Exploration Agency (JAXA) based on a quasi-physical SST algorithm and a Bayesian cloud screen method [18]. In [18], being evaluated against the buoy data which were measured at 20-30 cm, the ocean surface skin temperature of the H-8 SST data have a bias of $-0.16^{\circ} \mathrm{C}$ and a Root Mean Square Difference of $\sim 0.59^{\circ} \mathrm{C}$. After considering the "cool skin effect" of the skin temperate as compared with the buoy temperature, the accuracy of the H-8 SST data is deemed reliable.

Specifically, we used cloud-free daily H-8 SST data processed to Level 3, with the highest quality-levels of 4 and 5, representing skin SST according to the GHRSST standard and format. Note that in 2015 the time-series starts from 13 July when the H-8 data became available.

Upwelling often exhibits a colder SST signature than the adjacent area [5,15,16,23-28]. This negative local SST anomaly is the foundation of mapping upwelling using SST data. Ref. [4] demonstrated that the topographic position index (TPI) [29] was an appropriate method to identify and map the negative local SST anomaly in the upwelling study. In this study, a similar semi-automatic technique based on the TPI method was developed for mapping the coastal upwelling off the Taiwan east coast from the daily H-8 SST data.

The TPI is a local-based image processing algorithm [29] that has been successfully used to map the ocean currents [30,31] and the coastal upwelling [4]. In this study, the TPI was calculated from the daily H-8 SST data using a nominated circular window with a radius of 50 cells $(\sim 100 \mathrm{~km})$. This window size was deemed large enough to capture the coastal upwelling east of Taiwan. 
To map upwelling areas, firstly we selected areas of negative TPI values using a pre-defined threshold, satisfying the following condition:

$$
T P I \leq-S \_S D(T P I) \times \theta
$$

where the $S \_S D(T P I)$ is the spatial standard deviation of the TPI image; $\theta$ is a threshold which was set at 0.75 in this study. Next, we further selected only those areas that have an areal extent greater than $100 \mathrm{~km}^{2}$ as suitable upwelling candidates.

It was assumed that an upwelling area should have a reasonably large local SST anomaly (SST_A). The local SST anomaly of an upwelling candidate was calculated using the equation below:

$$
S S T_{-} A=S S T_{b}-S S T_{\mathcal{C}}
$$

where $S S T_{c}$ is the mean SST value of an upwelling candidate and $S S T_{b}$ is the mean SST value of the $20 \mathrm{~km}$ buffer around (but excluding) the upwelling candidate. An upwelling candidate was removed from the candidate set if its SST anomaly is less than a threshold, for example:

$$
S S T \_A<\delta
$$

where $\delta$ was set at $0.5^{\circ} \mathrm{C}$ in this study.

The threshold values of $\theta$ and $\delta$ were selected through a trial-and-error process and the experience gained from a previous upwelling study [4]. In the final step, only the upwelling candidates that are entirely or mainly within the $20 \mathrm{~km}$ buffer from the coast were regarded as coastal upwelling.

To examine the relationship between the upwelling-favorable winds and the coastal upwelling mapped from the H-8 SST data, a $20 \mathrm{~km}$ buffer was generated for each of the three wind locations (Figure 1). Within the $20 \mathrm{~km}$ buffer, one of three upwelling status was determined from the SST mapping results: (1) detected, when upwelling was detected within the buffer; (2) not-detected, when non-upwelling was detected within the buffer; (3) uncertain, when more than $50 \%$ of the buffer has no data in H-8 SST. Because the surface upwelling signature could lag behind a favorable wind event due to the travel time taken to uplift the deep water, the relationship was examined with three additional days extended to the end of each significant upwelling-favorable wind event.

\subsection{Analyzing Upwelling Characteristics}

After mapping the coastal upwelling east of Taiwan, we were able to quantitatively analyze several upwelling characteristics. As in [4], we calculated the area of influence (AoI), SST anomaly (SST_A), and chlorophyll- $a$ ratio (Chla_R) of the coastal upwelling. These three upwelling properties represent different proxies of upwelling strength.

The AoI was calculated as the areal extent of the mapped upwelling areas. The SST_A was calculated using Equation (6) as the difference between the mean SST value of the upwelling areas and the mean SST value of the study area (i.e., the $70 \mathrm{~km}$ buffer from the coast). Similarly, Chla_R was calculated as the ratio between the mean chlorophyll- $a$ concentration of the upwelling area and the mean chlorophyll- $a$ concentration of the study area. The data used to calculate Chla_R were the daily composites of H-8 chlorophyll- $a$ data processed by the JAXA to Level 3 using the algorithm developed in [32]. The spatial resolution of the chlorophyll- $a$ data is $\sim 5 \mathrm{~km}$. Note that these three characteristics were not calculated for those days when upwelling could only be partially mapped due to the cloud coverage.

\section{Results}

As examples, the H-8 SST image on 19 July 2016, the TPI image calculated from the SST image, and the corresponding chlorophyll- $a$ image are displayed in Figures 1 and 2 . Two upwelling areas were identified along the central and southern sections of the Taiwan east coast, with lower SST values, negative TPI values, and higher chlorophyll- $a$ concentrations than the offshore area. 


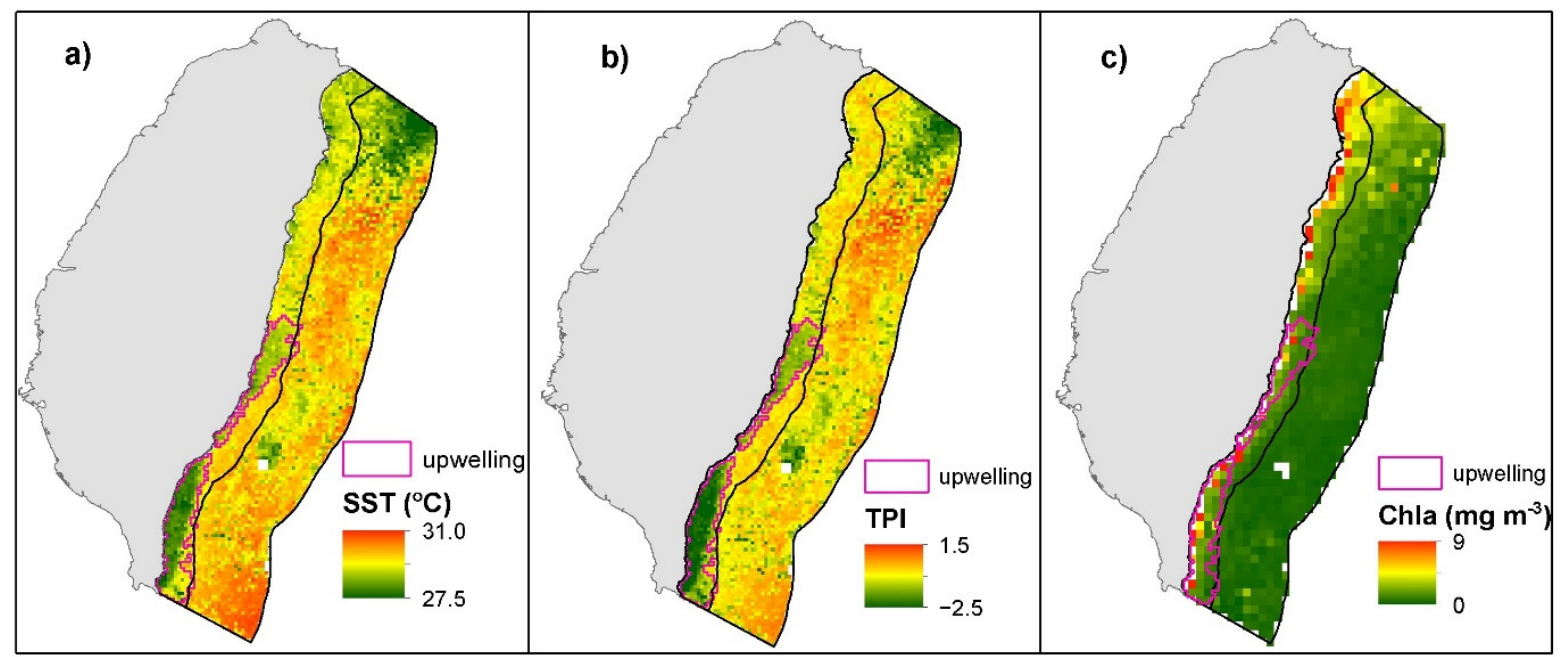

Figure 2. (a) The H-8 SST image on 19 July 2016, (b) the TPI image calculated from (a), (c) the H-8 chlorophyll- $a$ image on 19 July 2016. The purple polygons indicate the upwelling areas mapped.

\subsection{Coastal Upwelling with Significant Upwelling-Favorable Wind Events}

Each year between May and September during 2015-2019, several significant upwellingfavorable wind events were identified with variable durations along the east coast of Taiwan (Figures 3-5; Table 1). The wind events with the longest durations occur between June and August, lasting for more than 40 days (Figures 3-5; Table 1). At the northern location, the significant wind events usually start in late April and last into early October; while, at the southern and central locations, the wind events usually start in May or June and last only to mid-September (Figures 3-5). During the entire study period, the northern location experienced more such events (21 events) and lasted more days (340 days) than the central (14 events and 245 days) and southern (15 events and 265 days) locations (Table 2). On average, the southern and northern locations were influenced by much stronger upwellingfavorable winds than the central location, with the mean UI values of 1.37, 1.21, and $0.56 \mathrm{~m}^{2} \mathrm{~s}^{-1}$, respectively (Table 2).

The results show clear co-occurrence between the significant upwelling-favorable wind events and the detection of surface upwelling signature from the H-8 SST data, with an overall detection rate of $86.6 \% \pm 17.1 \%$ (Figures 3-5; Table 1). Specifically, the upwelling detection rates are $92.9 \% \pm 9.8 \%, 77.0 \% \pm 22.9 \%$, and $86.7 \% \pm 15.7 \%$ for the north, the central, and the south locations, respectively (Table 1). Indeed, the surface upwelling signature often persisted several days after the end of the wind events (Figures 3-5). Uncertainties often occurred on the dates of strong winds (Figures 3-5), which were likely associated with overcast or stormy weather conditions preventing the $\mathrm{H}-8$ sensor from acquiring cloud-free data. 


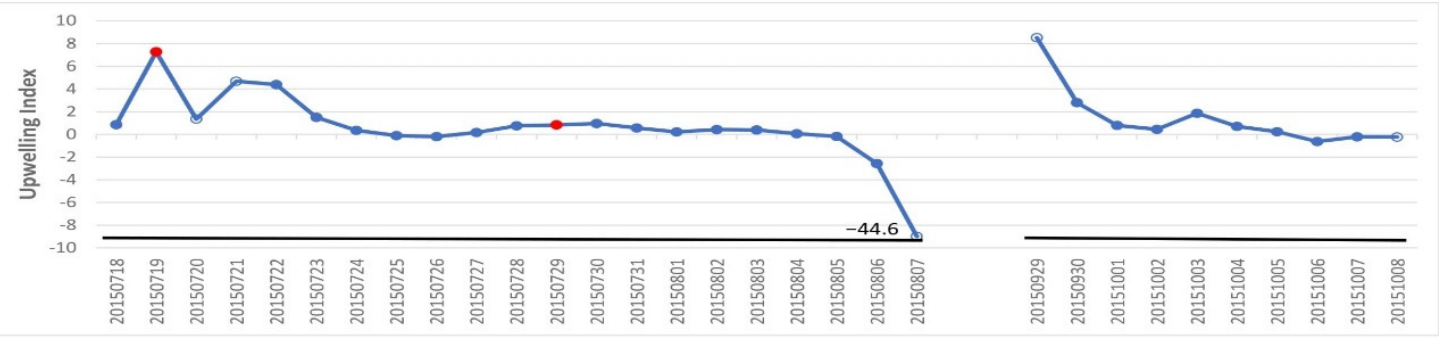

a)

b)
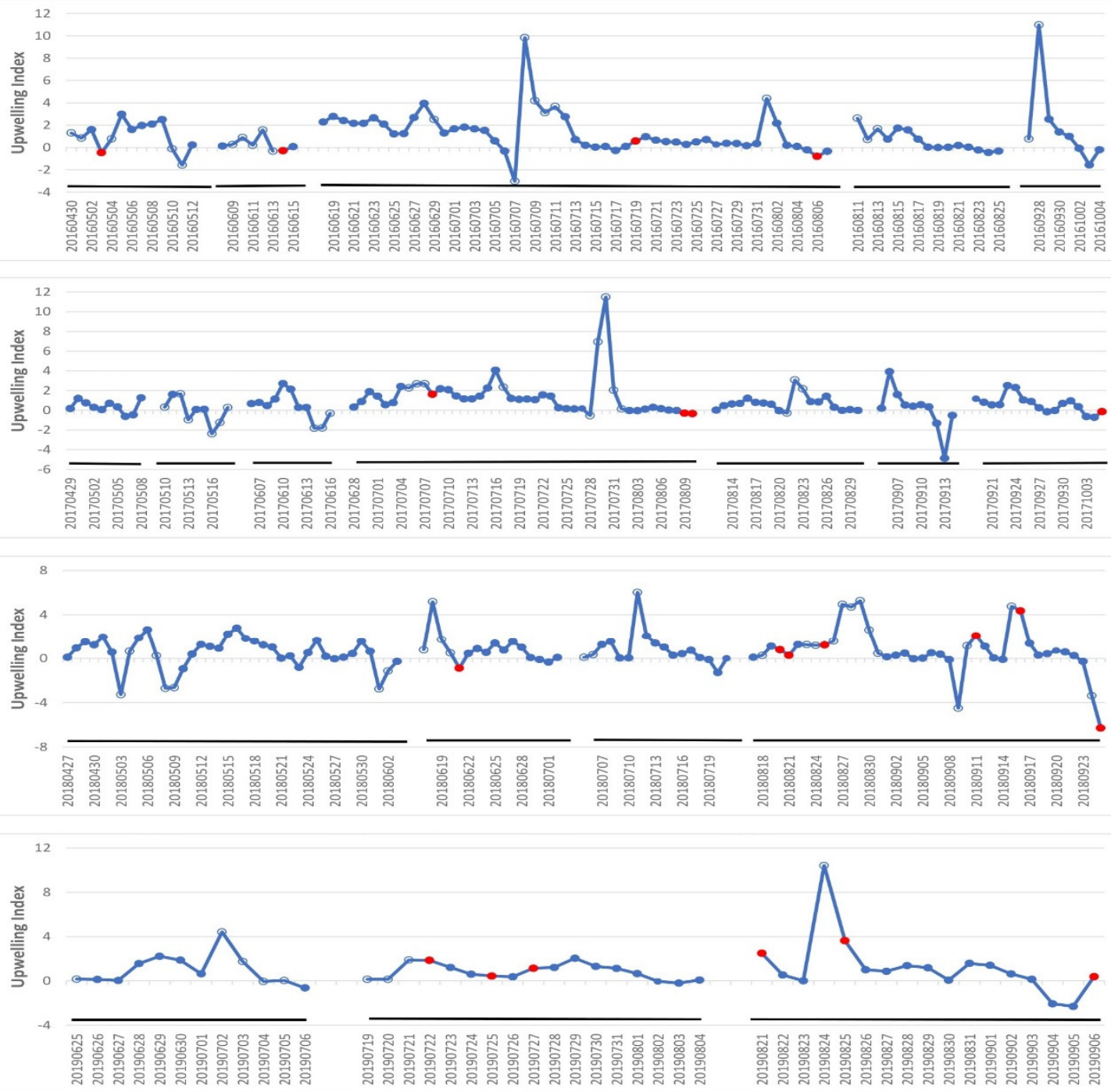

e)

Figure 3. Time-series of the significant upwelling-favorable wind events at the northern location; (a) 2015, (b) 2016, (c) 2017, (d) 2018, (e) 2019. The solid blue (red) circle indicates that the upwelling (non-upwelling) was detected at the location; while, the un-filled circle indicates that the upwelling status was uncertain because more than $50 \%$ of the $20 \mathrm{~km}$ buffer has no data in H-8 SST. The labelled value(s) are actual UI value(s) that could not be properly plotted. 


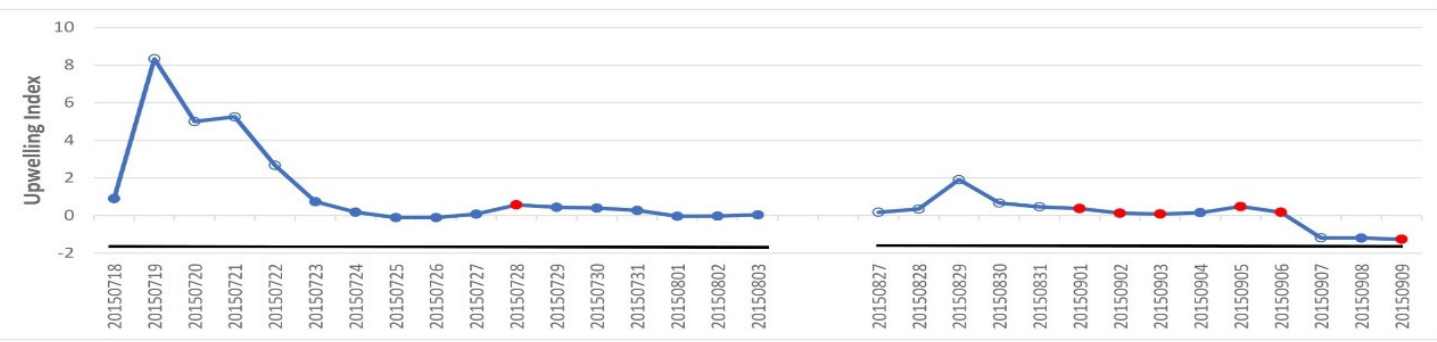

a)

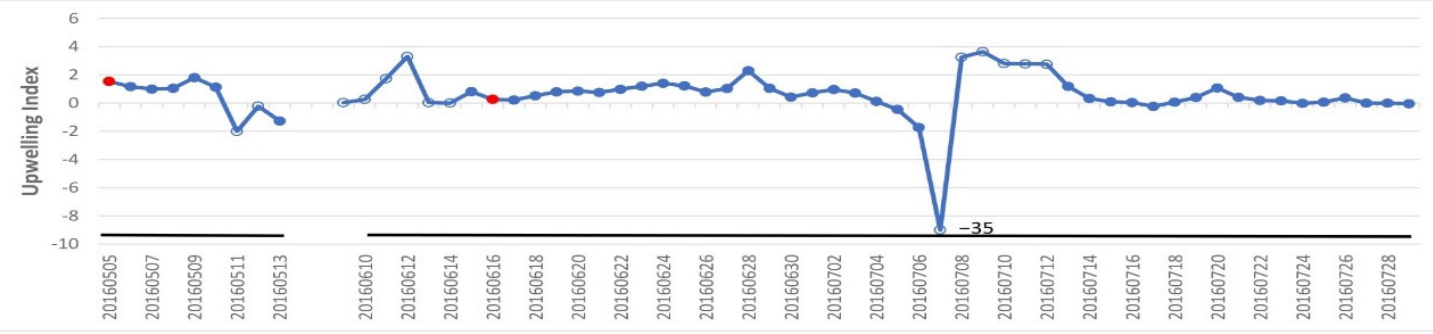

b)
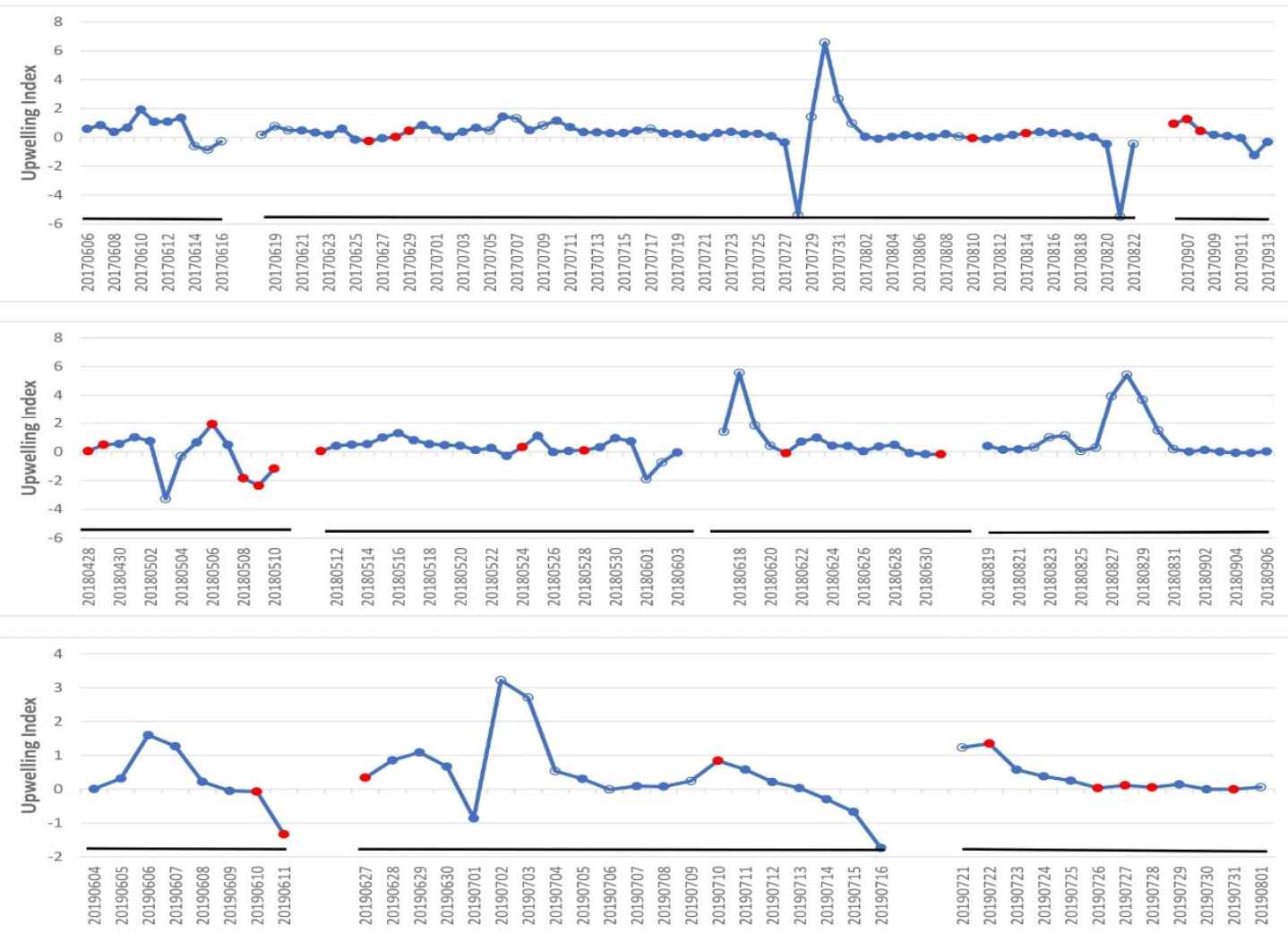

e)

Figure 4. Time-series of the significant upwelling-favorable wind events at the central location; (a) 2015, (b) 2016, (c) 2017, (d) 2018, (e) 2019. Symbols as Figure 3. The labelled value(s) are actual UI value(s) that could not be properly plotted. 


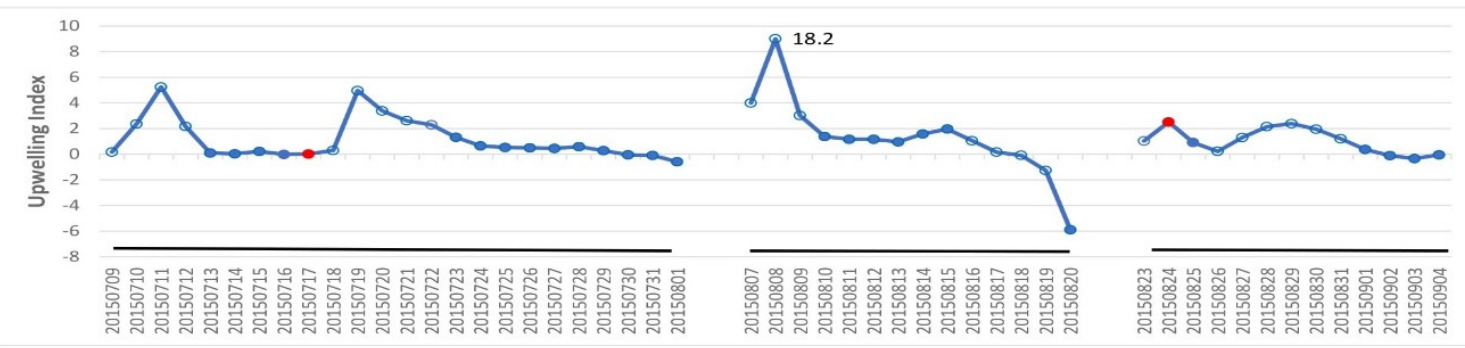

a)

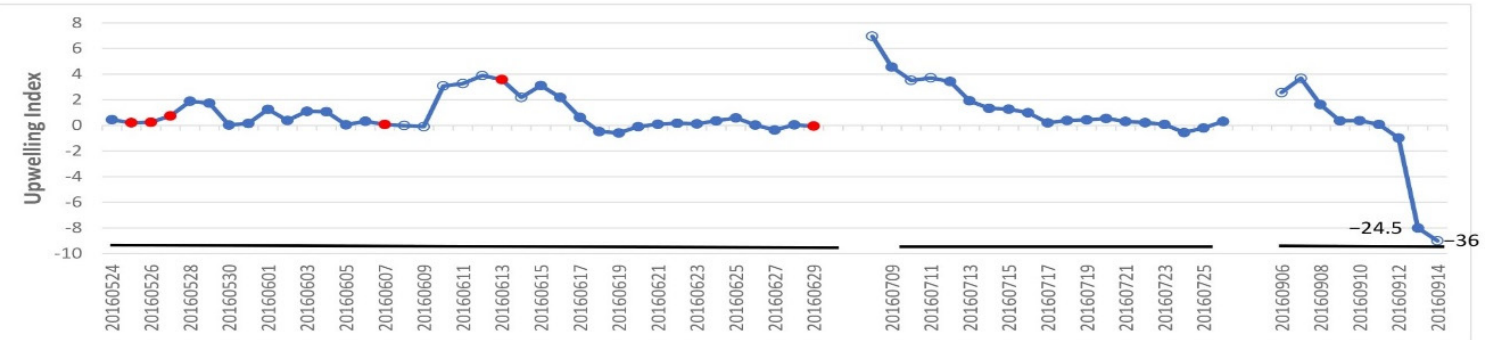

b)
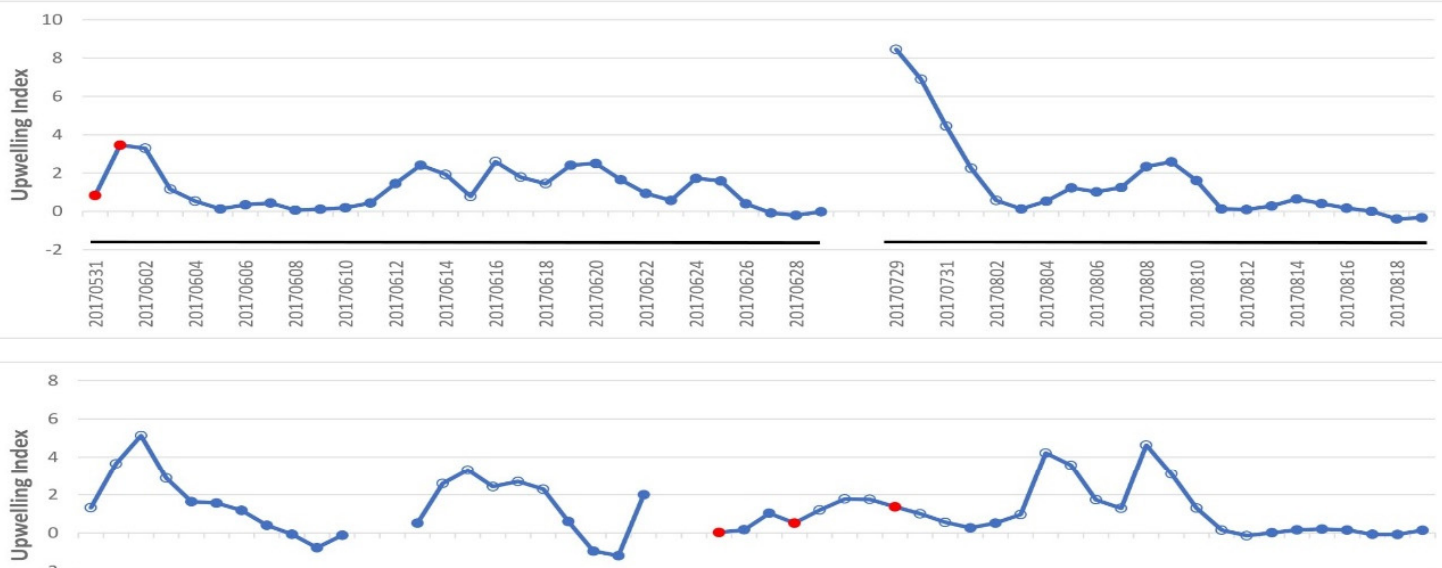

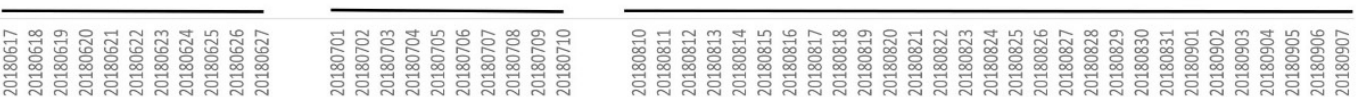

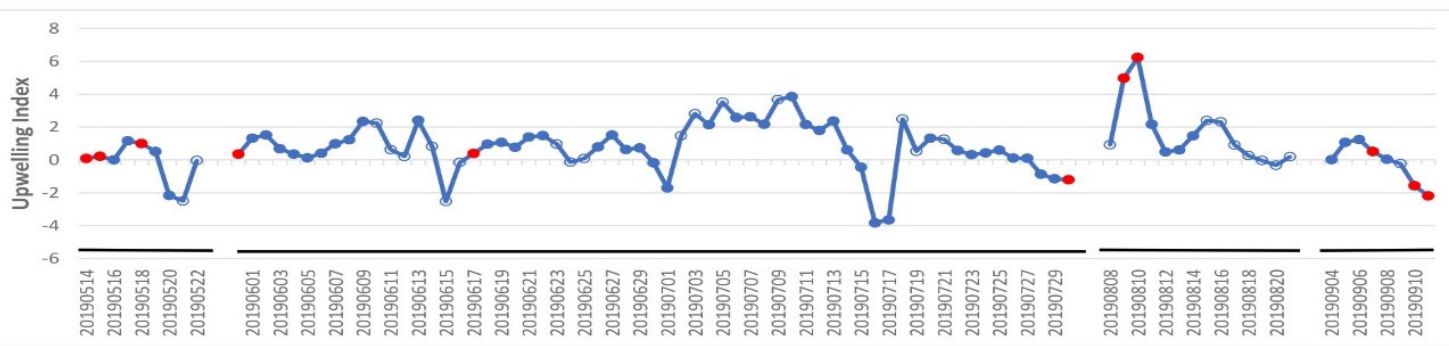

Figure 5. Time-series of the significant upwelling-favorable wind events at the southern location; (a) 2015, (b) 2016, (c) 2017, (d) 2018, (e) 2019. Symbols as Figure 3. The labelled value(s) are actual UI value(s) that could not be properly plotted. 
Table 1. The statistics of individual significant upwelling-favorable wind events and upwelling mapped from the H-8 SST data.

\begin{tabular}{|c|c|c|c|c|c|c|c|c|}
\hline Location & ID & Year & $\begin{array}{c}\text { Number of } \\
\text { Wind-Event Days }\end{array}$ & $\begin{array}{l}\text { Upwelling } \\
\text { Days }\end{array}$ & $\begin{array}{c}\text { Non-Upwelling } \\
\text { Days }\end{array}$ & $\begin{array}{c}\mathrm{UI5}^{1} \\
\left(\mathrm{~m}^{2} \mathrm{~s}^{-1}\right)\end{array}$ & Mean UI $\left(\mathrm{m}^{2} \mathrm{~s}^{-1}\right)$ & $\begin{array}{l}\text { Detection } \\
\text { Rate }^{2}\end{array}$ \\
\hline \multirow{21}{*}{ North } & 1 & \multirow{2}{*}{2015} & 18 & 16 & 2 & 18.54 & 1.36 & 88.89 \\
\hline & 2 & & 7 & 8 & 0 & 14.42 & 2.19 & 100.00 \\
\hline & 3 & \multirow{5}{*}{2016} & 10 & 7 & 1 & 4.08 & 1.53 & 87.50 \\
\hline & 4 & & 5 & 2 & 1 & 3.07 & 0.61 & 66.67 \\
\hline & 5 & & 48 & 42 & 2 & 11.82 & 1.48 & 95.45 \\
\hline & 6 & & 12 & 12 & 0 & 7.53 & 0.85 & 100.00 \\
\hline & 7 & & 5 & 6 & 0 & 16.68 & 3.34 & 100.00 \\
\hline & 8 & \multirow{7}{*}{2017} & 7 & 10 & 0 & 2.52 & 0.51 & 100.00 \\
\hline & 9 & & 6 & 3 & 0 & 2.71 & 0.47 & 100.00 \\
\hline & 10 & & 8 & 8 & 0 & 5.80 & 1.06 & 100.00 \\
\hline & 11 & & 41 & 32 & 3 & 5.12 & 1.58 & 91.43 \\
\hline & 12 & & 16 & 16 & 0 & 3.06 & 0.85 & 100.00 \\
\hline & 13 & & 7 & 9 & 0 & 6.68 & 1.08 & 100.00 \\
\hline & 14 & & 14 & 14 & 1 & 5.62 & 0.86 & 93.33 \\
\hline & 15 & \multirow{4}{*}{2018} & 35 & 31 & 0 & 5.76 & 0.60 & 100.00 \\
\hline & 16 & & 13 & 11 & 1 & 7.31 & 1.08 & 91.67 \\
\hline & 17 & & 14 & 14 & 0 & 3.27 & 1.10 & 100.00 \\
\hline & 18 & & 37 & 21 & 6 & 2.58 & 1.12 & 77.78 \\
\hline & 19 & \multirow{3}{*}{2019} & 9 & 7 & 0 & 4.12 & 1.42 & 100.00 \\
\hline & 20 & & 14 & 11 & 3 & 5.26 & 1.01 & 78.57 \\
\hline & 21 & & 14 & 11 & 3 & 17.08 & 1.81 & 78.57 \\
\hline \multirow{14}{*}{ Centre } & 1 & \multirow{2}{*}{2015} & 14 & 12 & 1 & 22.16 & 1.76 & 92.31 \\
\hline & 2 & & 11 & 2 & 6 & 3.56 & 0.45 & 25.00 \\
\hline & 3 & \multirow{2}{*}{2016} & 6 & 6 & 1 & 6.55 & 1.28 & 85.71 \\
\hline & 4 & & 48 & 38 & 1 & 5.35 & 0.09 & 97.44 \\
\hline & 5 & \multirow{3}{*}{2017} & 8 & 8 & 0 & 4.38 & 0.98 & 100.00 \\
\hline & 6 & & 63 & 46 & 5 & 2.24 & 0.38 & 90.20 \\
\hline & 7 & & 5 & 5 & 3 & 2.89 & 0.58 & 62.50 \\
\hline & 8 & \multirow{4}{*}{2018} & 10 & 5 & 6 & 2.83 & 0.23 & 45.45 \\
\hline & 9 & & 21 & 19 & 3 & 2.47 & 0.46 & 86.36 \\
\hline & 10 & & 12 & 9 & 2 & 9.10 & 1.04 & 81.82 \\
\hline & 11 & & 16 & 9 & 0 & 2.02 & 1.14 & 100.00 \\
\hline & 12 & \multirow{3}{*}{2019} & 5 & 6 & 2 & 3.40 & 0.68 & 75.00 \\
\hline & 13 & & 17 & 13 & 2 & 2.08 & 0.64 & 86.67 \\
\hline & 14 & & 9 & 5 & 5 & 3.78 & 0.46 & 50.00 \\
\hline \multirow{15}{*}{ South } & 1 & \multirow{3}{*}{2015} & 21 & 14 & 1 & 10.02 & 1.34 & 93.33 \\
\hline & 2 & & 11 & 7 & 0 & 27.78 & 3.15 & 100.00 \\
\hline & 3 & & 10 & 5 & 1 & 5.98 & 1.41 & 83.33 \\
\hline & 4 & \multirow{3}{*}{2016} & 34 & 25 & 6 & 3.53 & 0.94 & 80.65 \\
\hline & 5 & & 16 & 15 & 0 & 22.17 & 1.87 & 100.00 \\
\hline & 6 & & 6 & 6 & 0 & 8.58 & 1.44 & 100.00 \\
\hline & 7 & \multirow{2}{*}{2017} & 27 & 20 & 2 & 9.26 & 1.30 & 90.91 \\
\hline & 8 & & 19 & 17 & 0 & 22.61 & 1.84 & 100.00 \\
\hline & 9 & \multirow{3}{*}{2018} & 8 & 7 & 0 & 14.60 & 2.22 & 100.00 \\
\hline & 10 & & 7 & 4 & 0 & 11.51 & 2.06 & 100.00 \\
\hline & 11 & & 26 & 11 & 3 & 2.91 & 1.21 & 78.57 \\
\hline & 12 & \multirow{4}{*}{2019} & 6 & 4 & 3 & 2.46 & 0.50 & 57.14 \\
\hline & 13 & & 58 & 42 & 3 & 4.23 & 0.92 & 93.33 \\
\hline & 14 & & 11 & 4 & 2 & 14.78 & 2.07 & 66.67 \\
\hline & 15 & & 5 & 4 & 3 & 2.88 & 0.58 & 57.14 \\
\hline
\end{tabular}


Table 2. The statistics of the significant upwelling-favorable wind events and the mapping of coastal upwelling at the three locations of east Taiwan, during the five extended summer seasons (May to September) between 2015 and 2019.

\begin{tabular}{cccccccc}
\hline Location & $\begin{array}{c}\text { Number of } \\
\text { Wind Events }\end{array}$ & $\begin{array}{c}\text { Number of } \\
\text { Wind-Event Days }\end{array}$ & $\begin{array}{c}\text { Mean (Median) } \\
\left.\text { UI } \mathbf{( m}^{\mathbf{2}} \mathbf{s}^{-\mathbf{1}}\right)\end{array}$ & $\begin{array}{c}\text { Upwelling } \\
\text { Days }\end{array}$ & $\begin{array}{c}\text { Non-Upwelling } \\
\text { Days }\end{array}$ & $\begin{array}{c}\text { Uncertainty } \\
\text { Days }\end{array}$ \\
\hline North & 21 & 340 & $1.21(0.80)$ & 291 & 23 & 89 \\
\hline Central & 14 & 245 & $0.56(0.40)$ & 183 & 37 & 67 \\
\hline South & 15 & 265 & $1.37(0.99)$ & 185 & 24 & 101 \\
\hline
\end{tabular}

\subsection{Upwelling Maps}

To examine the overall spatial pattern of the coastal upwelling east of Taiwan, we generated an upwelling frequency map by combining the daily upwelling maps of those upwelling dates that have complete H-8 SST data $(n=291)$ during the entire study period (Figure 6a). The overall spatial pattern shows that during the significant wind events, upwelling can occur along the entire east coast of Taiwan (Figure 6a). In general, further away from the coast, less frequent coastal upwelling occurs. Although upwelling could extend more than $20 \mathrm{~km}$ offshore, most of the upwelling occurs within $20 \mathrm{~km}$ off the coast (Figure 6a). In particular, the northern and southernmost coastal areas experience upwelling more often, with a frequency greater than $70 \%$ (Figure $6 \mathrm{a}$ ). In terms of spatial extent, the areas with high (70-90\%), moderate (30-70\%) and low (10-30\%) upwelling frequency are $15 \%\left(\sim 1250 \mathrm{~km}^{2}\right), 44 \%\left(\sim 3820 \mathrm{~km}^{2}\right)$ and $41 \%\left(\sim 3570 \mathrm{~km}^{2}\right)$, respectively (Figure $\left.7 \mathrm{a}\right)$.
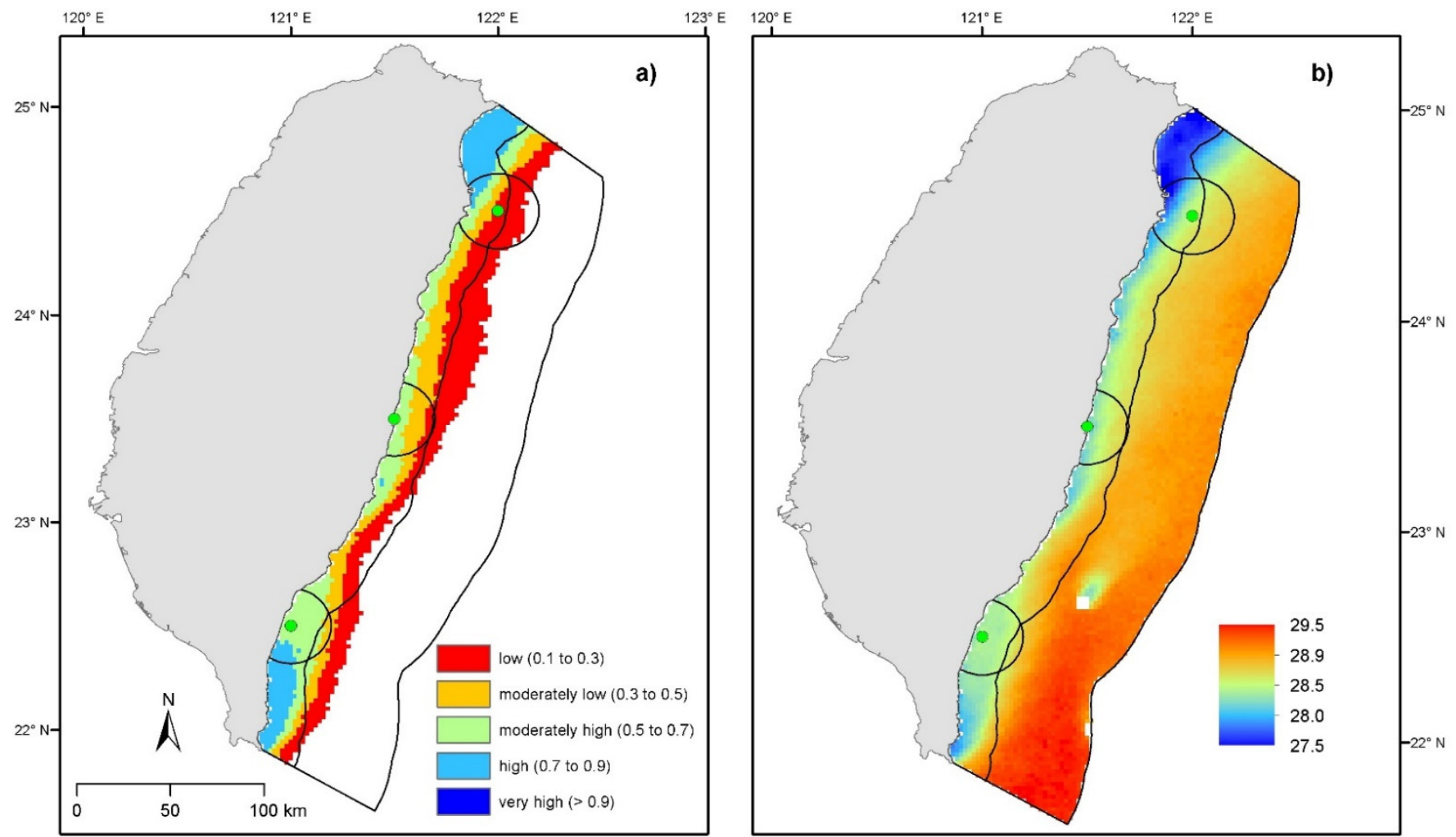

Figure 6. The overall upwelling frequency map (a) vs the overall temporally-averaged SST map (b); generated by combining the daily upwelling maps and SST maps of all upwelling dates $(n=291)$ together. The frequency is divided into five categories: low, moderately low, moderately high, high, and very high. 


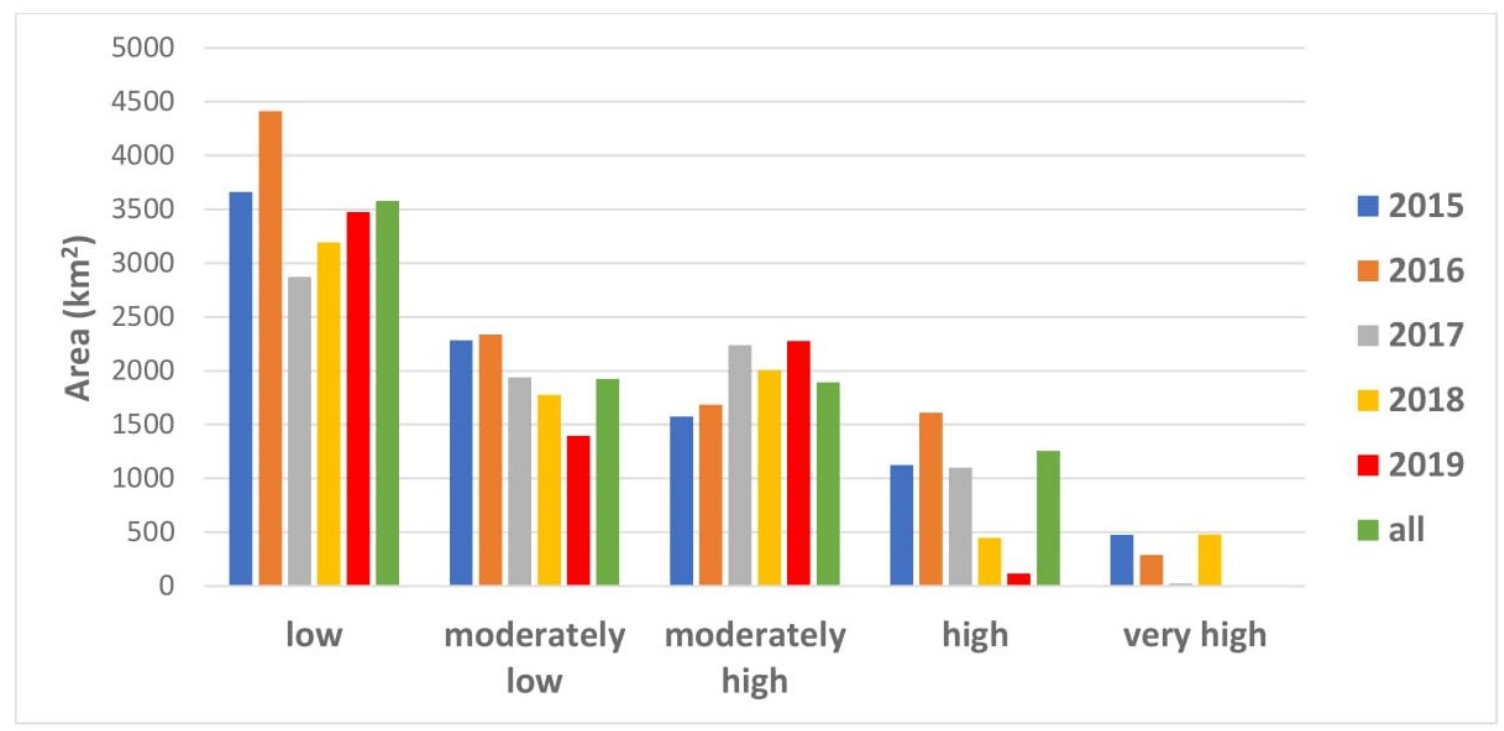

a)

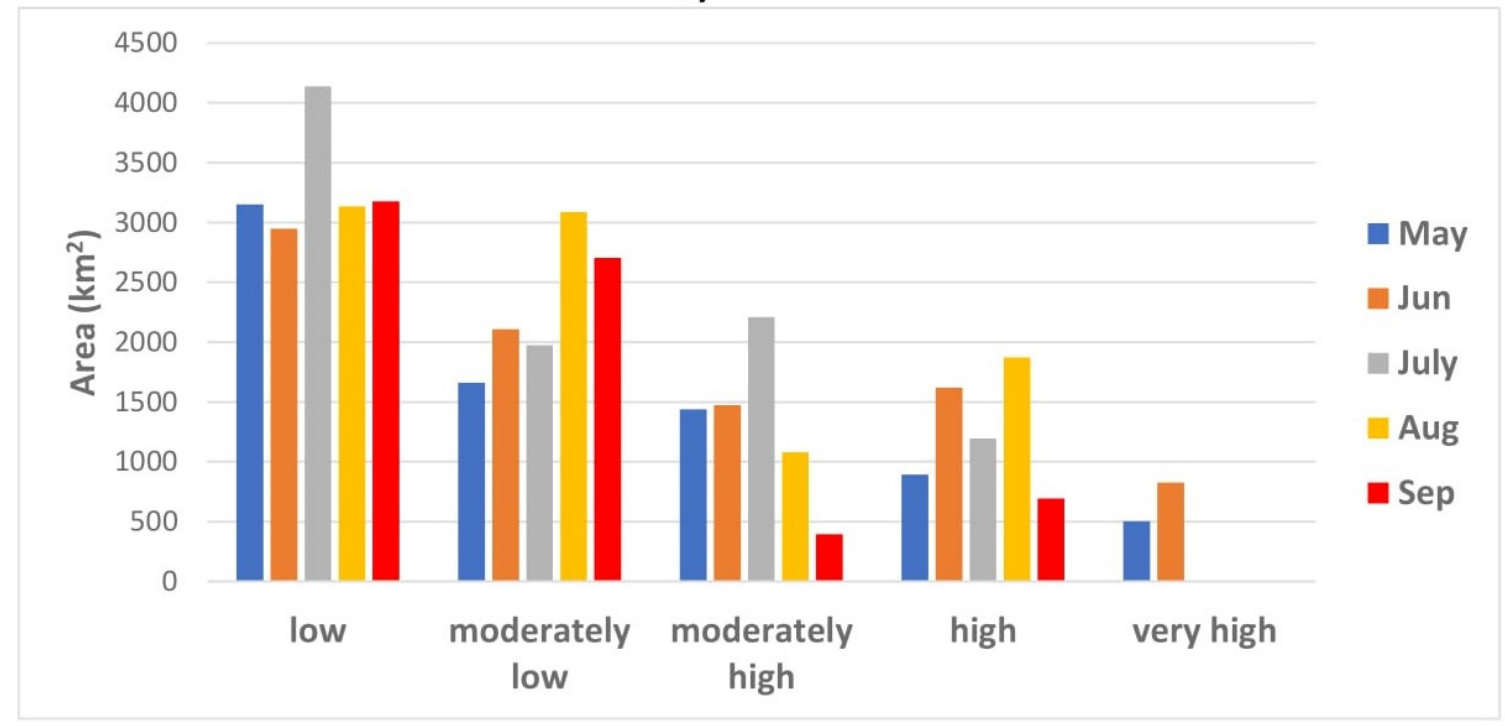

b)

Figure 7. The areas of the upwelling frequency maps generated for (a) the inter-annual variation (Figure 9) and (b) the monthly variation (Figure 8).

There are substantial intra-seasonal variations in upwelling extent (Figure 8$)$. The upwelling area increases substantially from May $\left(\sim 7648 \mathrm{~km}^{2}\right)$ to June $\left(\sim 8976 \mathrm{~km}^{2}\right)$ and July $\left(\sim 9516 \mathrm{~km}^{2}\right)$, especially at the northern section of the Taiwan east coast, then decreases slightly in August $\left(\sim 9176 \mathrm{~km}^{2}\right)$ and further reduces in September $\left(\sim 6968 \mathrm{~km}^{2}\right)$. Three upwelling centers (north, central, and south), with greater than $70 \%$ of upwelling frequency, are clearly visible from May to July (Figure $8 \mathrm{a}-\mathrm{c}$ ). The central upwelling center disappears in August; and by September, only the northern upwelling center still remains (Figure 8d,e). In May, the coastal upwelling almost always ( $>90 \%$ frequency) occurs at the northern center, as well as at a tiny area near the southern tip of the southern upwelling center (Figure 8a). In June, the extents of the three upwelling centers expand, with an increased and a reduced area experiencing a very-high frequency of upwelling at the southern center and the northern center, respectively (Figure $8 b$ ). In terms of spatial extent, the area experiencing very-high frequency upwelling occupies $\sim 500 \mathrm{~km}^{2}$ and $\sim 830 \mathrm{~km}^{2}$ in May and June, respectively (Figure $7 \mathrm{~b}$ ). The largest area with a high frequency of upwelling occurs in August $\left(\sim 1870 \mathrm{~km}^{2}\right)$, followed by June $\left(\sim 1620 \mathrm{~km}^{2}\right)$. 


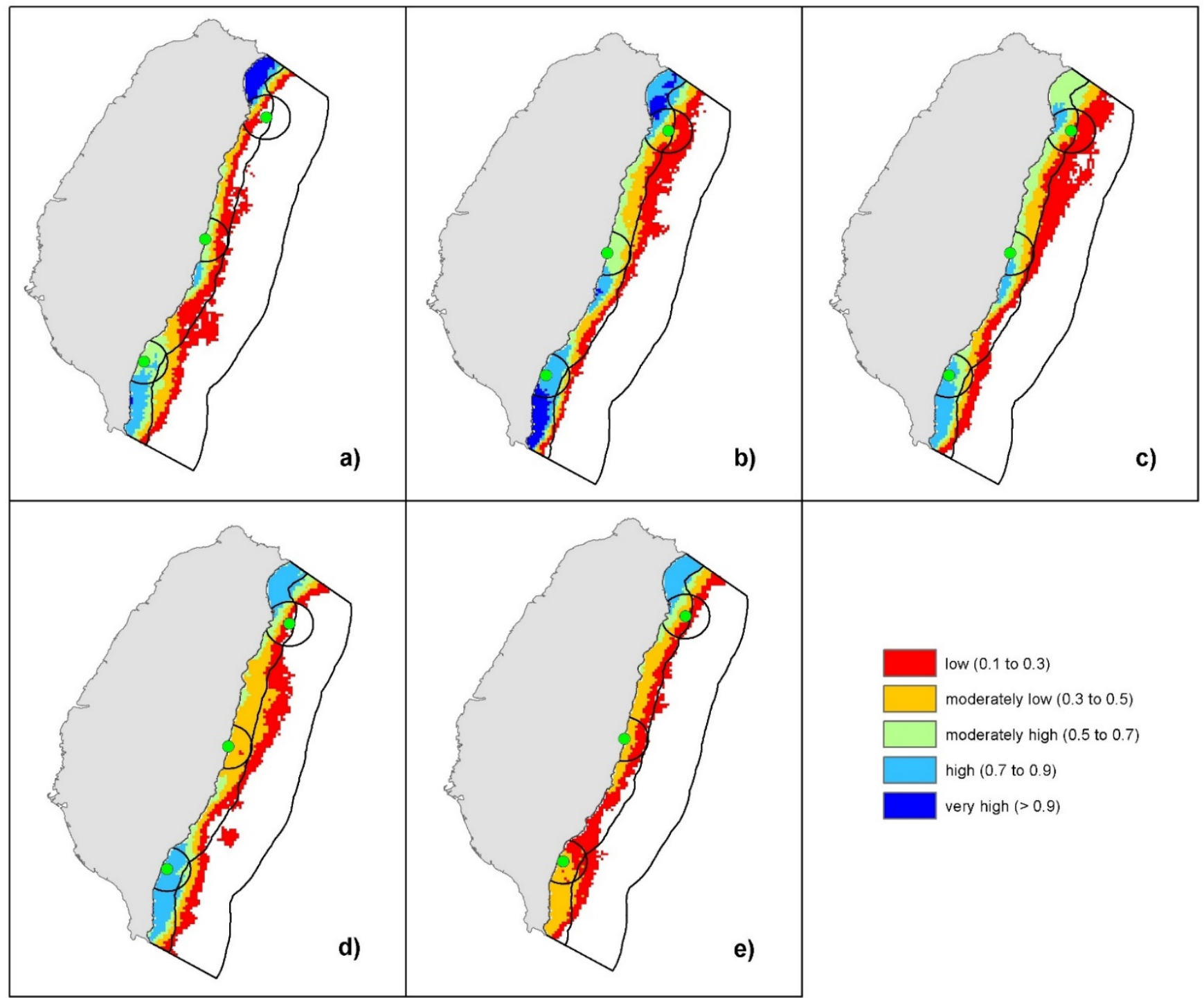

Figure 8. The monthly upwelling frequency map were generated by combining the daily upwelling maps of the corresponding months; (a) May, (b) June, (c) July, (d) August, (e) September. The frequency is divided into five categories: low, moderately low, moderately high, high, and very high.

There are also substantial interannual variations in upwelling extent (Figures 7a and 9). The total upwelling area was the largest in $2016\left(\sim 10330 \mathrm{~km}^{2}\right)$, followed by in 2015 $\left(\sim 9120 \mathrm{~km}^{2}\right)$, and the smallest in $2019\left(\sim 7260 \mathrm{~km}^{2}\right)$. The three upwelling centers were clearly visible in 2016, 2017, and 2018 (Figure 9b-d). The very-high frequency of upwelling occurred at part of the southern section in 2015 and 2016, and at part of the northern section in 2018 (Figure 9a,b,d). Overall, the coastal upwelling occurred less frequently in 2019 than that in other years. In total, the year 2016 had the largest upwelling area with high and very-high upwelling frequency $\left(\sim 1900 \mathrm{~km}^{2}\right)$, followed by the year 2015 $\left(\sim 1600 \mathrm{~km}^{2}\right)$ (Figure 7a). 


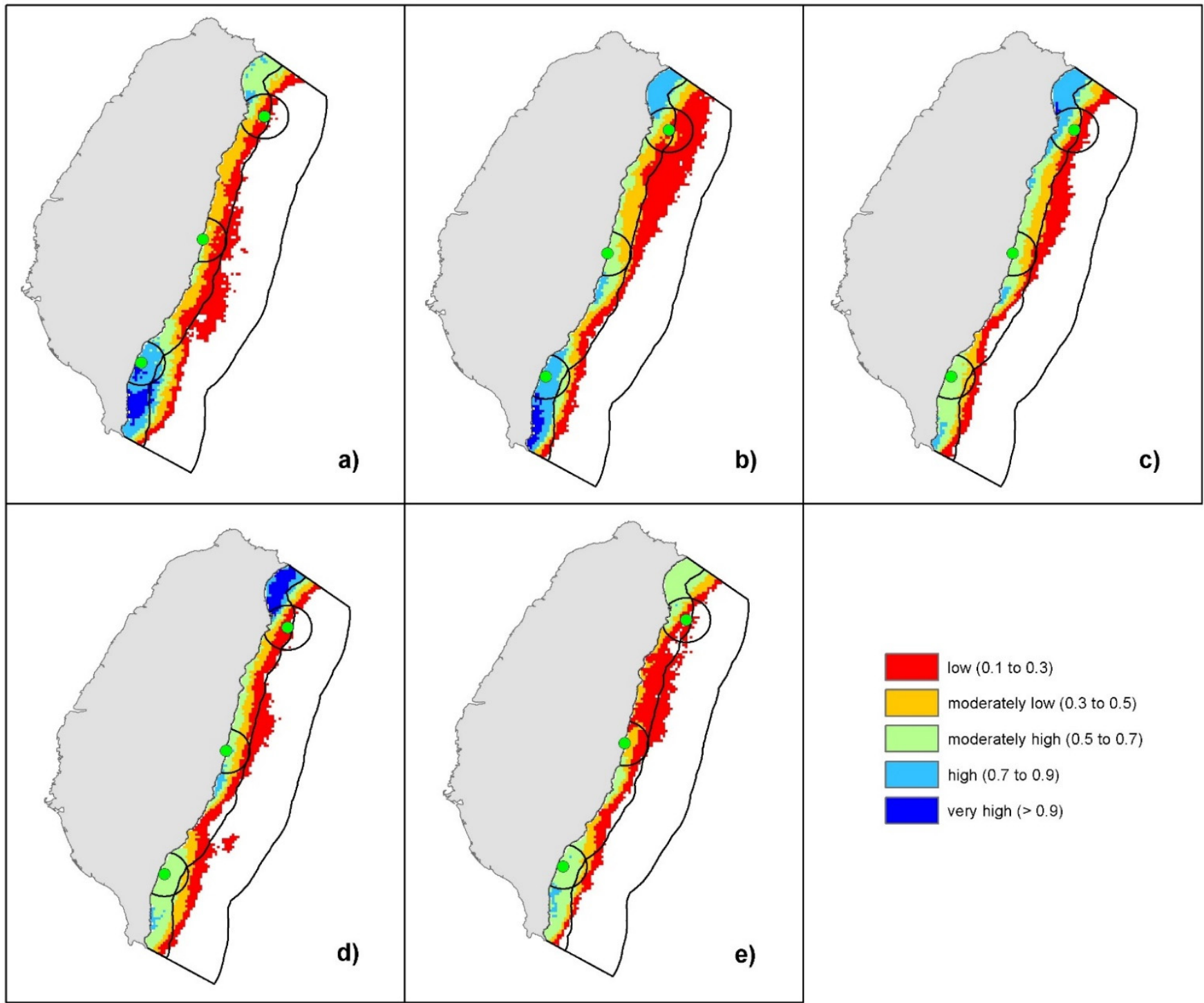

Figure 9. The inter-annual upwelling frequency maps were generated by combining the daily upwelling maps of the corresponding years; (a) 2015, (b) 2016, (c) 2017, (d) 2018, (e) 2019. The frequency is divided into five categories: low, moderately low, moderately high, high, and very high.

\subsection{Upwelling Characteristics}

The monthly mean upwelling area is highest in June $\left(\sim 5200 \mathrm{~km}^{2}\right)$ and lowest in September $\left(\sim 3100 \mathrm{~km}^{2}\right)$ (Figure 10a). Statistically, the monthly mean upwelling area is significantly higher in June than that in September or in May; while, it is significantly higher in July and August than that in September. The monthly mean SST anomaly between the upwelling area and the study area (the $70 \mathrm{~km}$ buffer) is largest $\left(0.99{ }^{\circ} \mathrm{C}\right)$ in May but smallest $\left(0.76^{\circ} \mathrm{C}\right)$ in August (Figure 10b). Statistically, the monthly mean upwelling's $S S T \_A$ is significantly higher in May and September than that in August. In terms of chlorophyll- $a$ ratio between the upwelling area and the study area, the monthly mean Chla_R is the largest (3.1) in September, which is significantly higher than that (2.1-2.2) in all other months statistically (Figure 10c). 

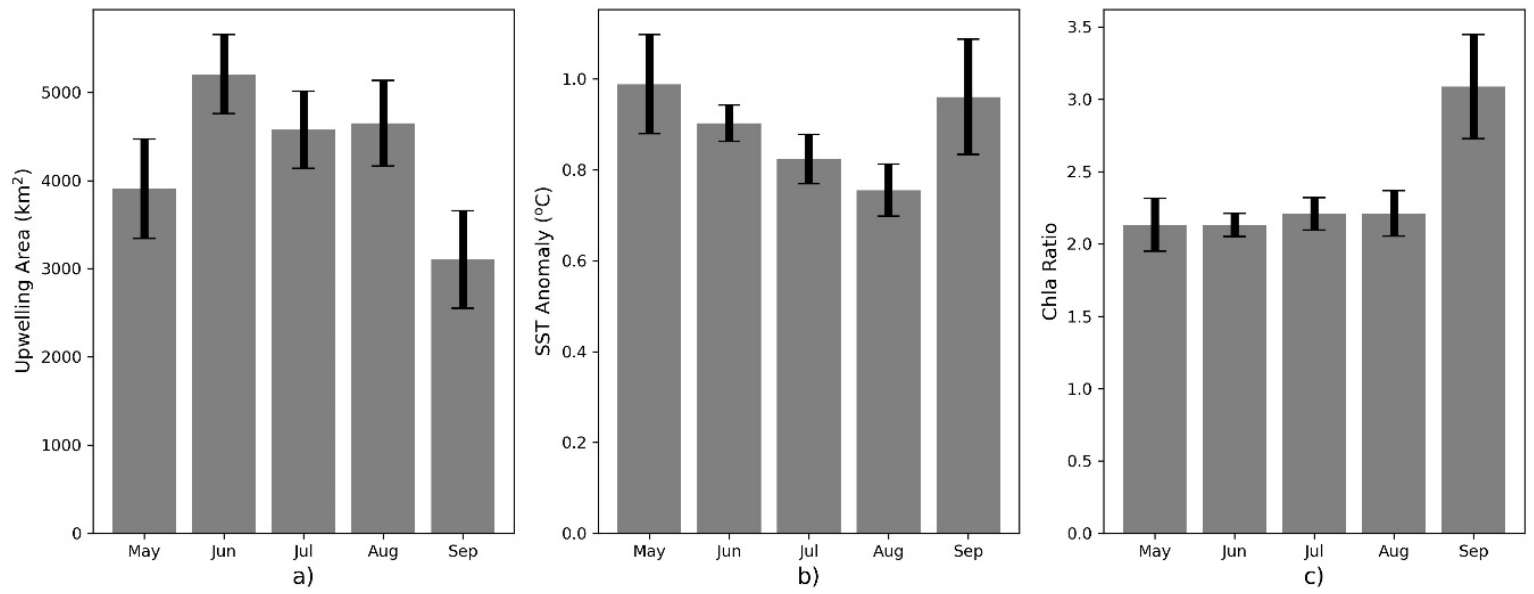

Figure 10. The monthly variation of upwelling's characteristics; (a) the upwelling area, (b) the upwelling's SST anomaly, (c) the upwelling's chlorophyll- $a$ ratio. The error bars indicate $95 \%$ confidence intervals.

In terms of interannual variation, the annual mean upwelling area was highest in 2016 $\left(\sim 5125 \mathrm{~km}^{2}\right)$ and continued to reduce in the following three years (Figure 11a). Statistically, the annual mean upwelling area in 2016 was significantly higher than that in all of the following three years; while, the annual mean upwelling area $\left(\sim 4270 \mathrm{~km}^{2}\right)$ in 2017 was also significantly higher than that $\left(\sim 3250 \mathrm{~km}^{2}\right)$ in 2019 . The annual mean SST anomaly was the largest $\left(1.0^{\circ} \mathrm{C}\right)$ in 2018 and the lowest $\left(0.81^{\circ} \mathrm{C}\right)$ in 2017 (Figure $\left.11 \mathrm{~b}\right)$. Their difference was statistically significant. The annual mean Chla_R was the highest (2.5) in 2018, and the lowest (2.2) in 2016 (Figure 11c). However, the differences between these four years were not statistically significant.
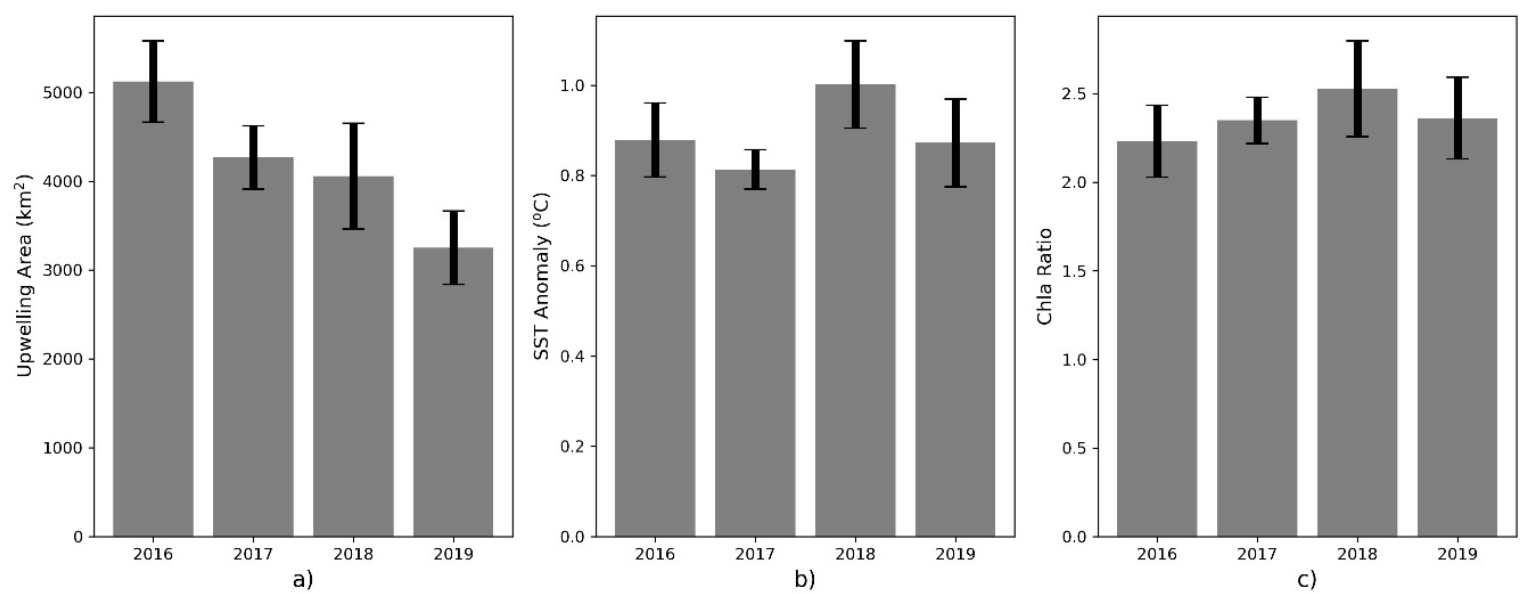

Figure 11. The interannual variations of the upwelling characteristics; (a) upwelling area, (b) SST anomaly, (c) Chla ratio. The year 2015 is not included as it is an incomplete year of data. The error bars indicate $95 \%$ confidence intervals.

\section{Discussion}

This study shows clear evidence of seasonal coastal upwelling along the Taiwan east coast (Figures 6a and 8). The coastal upwelling is mainly detected during the summer monsoon season when the southwesterly/southerly winds are upwelling-favorable (Figures 3-5). The coastal upwelling is hence believed to be wind-driven, with a similar mechanism as the coastal upwelling along the Fujian coast on the western side of the Taiwan Strait $[3,12,13]$. There are two pieces of additional evidence to support this finding. Firstly, a greater number of days with significant upwelling-favorable winds is associated with a greater 
number of upwelling days, both at the level of individual wind events $(\mathrm{r}=0.96 ; \mathrm{n}=50$; $p<0.001$; Figure 12a) and at the level of the upwelling centers $(\mathrm{r}=0.98 ; \mathrm{n}=3 ; p<0.01$; Table 2). Secondly, a stronger wind-driven upwelling index is also associated with a higher upwelling detection rate $(\mathrm{r}=0.80 ; \mathrm{n}=3 ; p<0.1$; Table 2$)$, although the positive correlation at the level of individual wind events is relatively weak $(r=0.40 ; n=50 ; p<0.01$; Figure $12 b)$.

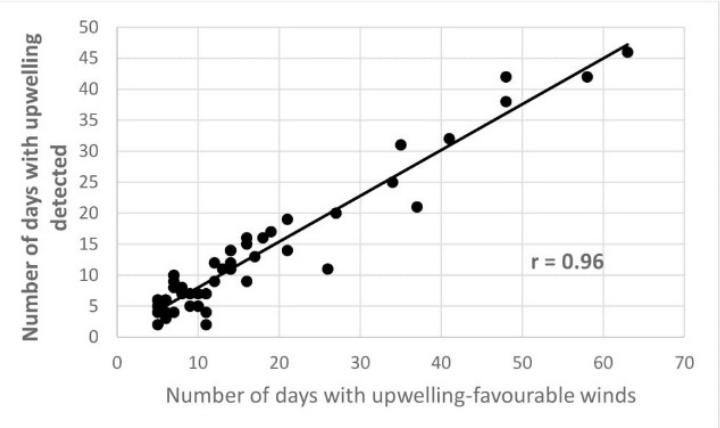

a)

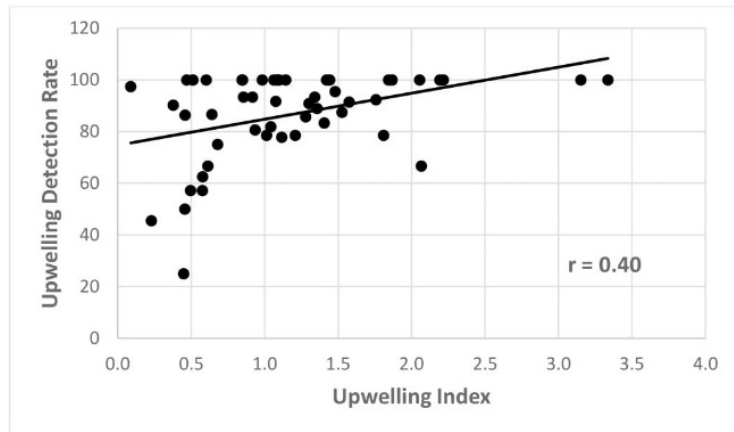

b)

Figure 12. (a) Correlation between the number of days with upwelling-favorable winds and the number of days with upwelling detected from the H-8 SST data $(n=50)$; $(\mathbf{b})$ correlation between the wind-driven upwelling index and the upwelling detection rate from the H-8 SST data. Each point represents one significant upwelling-favorable wind event ( $\mathrm{n}=50)$.

Although upwelling can be detected along the entire east coast of Taiwan, it generally occurs around three upwelling centers (Figures $6 a, 8$ and 9). However, there are clear spatial and temporal variabilities among the three upwelling centers. The northern and southern upwelling centers are persistent upwelling centers during the summer monsoon season; while, the central upwelling center, which can be absent in some months and years, is much weaker in intensity (Figures 8 and 9; Tables 1 and 2). Upwelling occurs more often at the northern and southern sections of the coast, most likely due to a larger number of days with significant upwelling-favorable winds and an overall stronger upwelling index (Tables 1 and 2). In particular, the northern upwelling center usually has the longest upwelling season, lasting through the entire extended summer season from May to September (Figure 8), which is most likely because of the prolonged summer monsoon season at this location (Figure 3). The upwelling's spatial patterns mapped in this study (Figures 6a, 8 and 9) generally agree with those of the temporally-averaged SST maps (Figures $6 \mathrm{~b}, 13$ and 14). In particular, the three upwelling centers, which have lower SST than the offshore area, are also clearly visible in the temporally-averaged SST maps. This confirms the reliability of the semi-automatic upwelling mapping technique used in this study.

The upwelling areas are larger in the main summer monsoon season between June and August than those in the transition period of May and September (Figures 8 and 10a). This is likely due to the higher upwelling index in these months (Figure 15). Larger upwelling areas in June-August coincide with lower upwelling SST anomaly (Figure 10a,b). This might be because upwelling in June-August could be sourced from relatively shallower (and warmer) water than that in May and September, due to a stronger summer thermocline barrier [33]. A much higher chlorophyll- $a$ ratio in September than that in other months (Figure 10c) is due to higher chlorophyll- $a$ concentrations (up to $0.7 \mathrm{mg} \mathrm{m}^{-3}$ ) in the upwelling areas. This could be due to, at the beginning of autumn, the strong summer thermocline barrier becomes weaker, and surface cooling leads to deeper mixed layer depth [33], and as a result, nutrients from deeper waters can be uplifted to the surface during an upwelling event in early autumn. It should be noted that, however, this study could not separate chlorophyll- $a$ of the terrestrial source from that of the upwelling source [9]. 


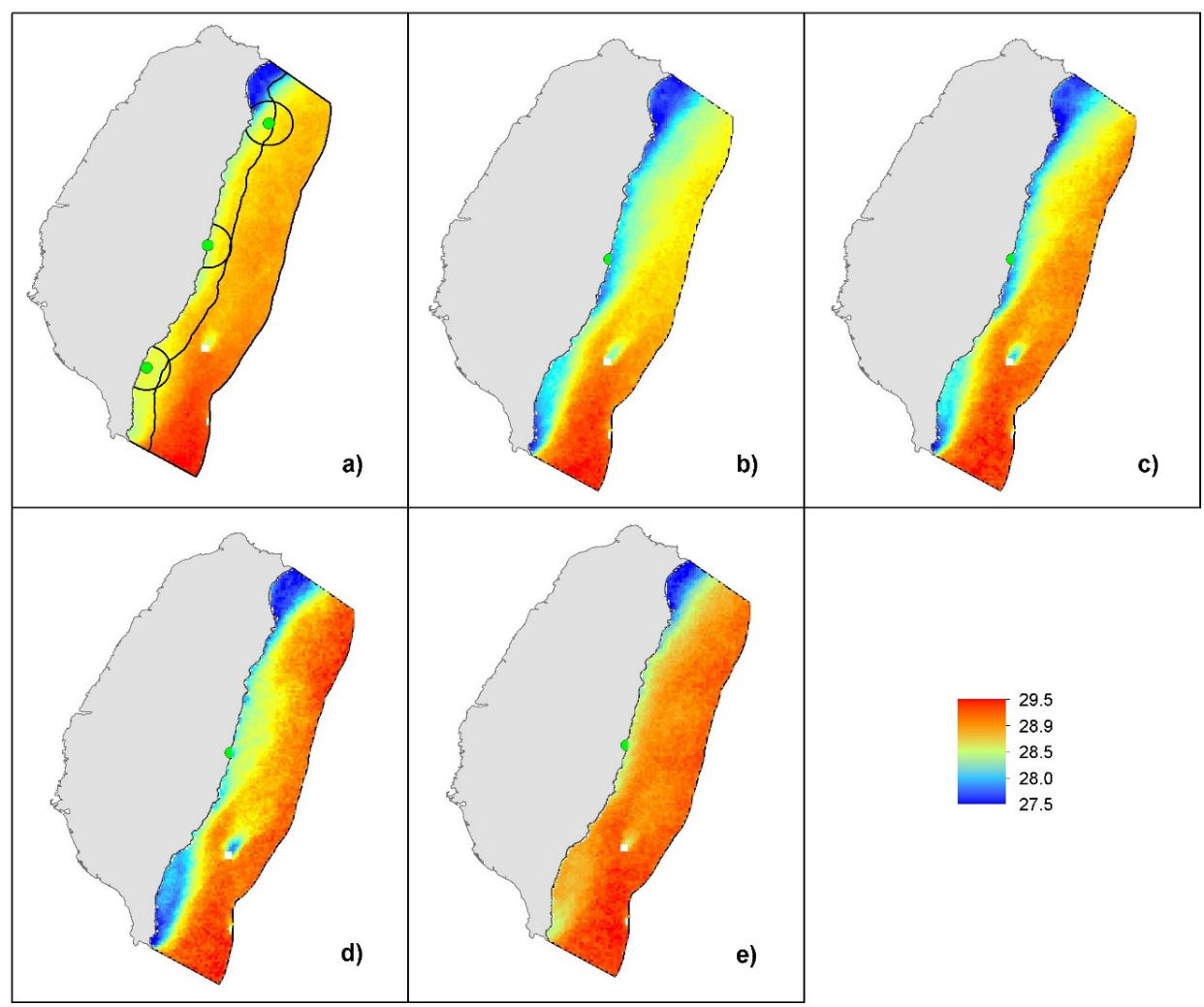

Figure 13. The monthly-averaged SST maps were generated by combining the daily SST maps of the corresponding months; (a) May, (b) June, (c) July, (d) August, (e) September.

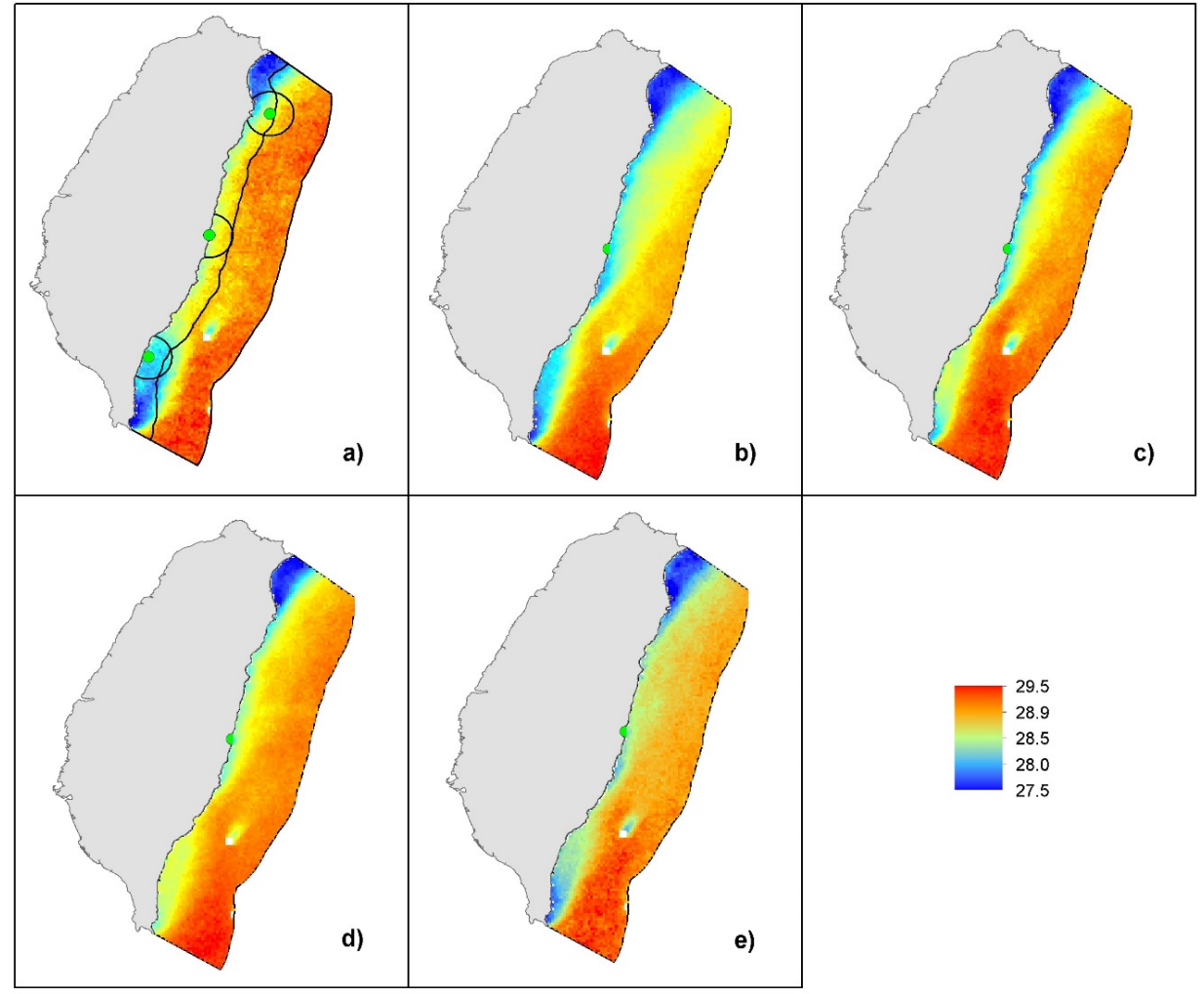

Figure 14. The annually-averaged SST maps were generated by combining the daily SST maps of the corresponding years; (a) 2015, (b) 2016, (c) 2017, (d) 2018, (e) 2019. 

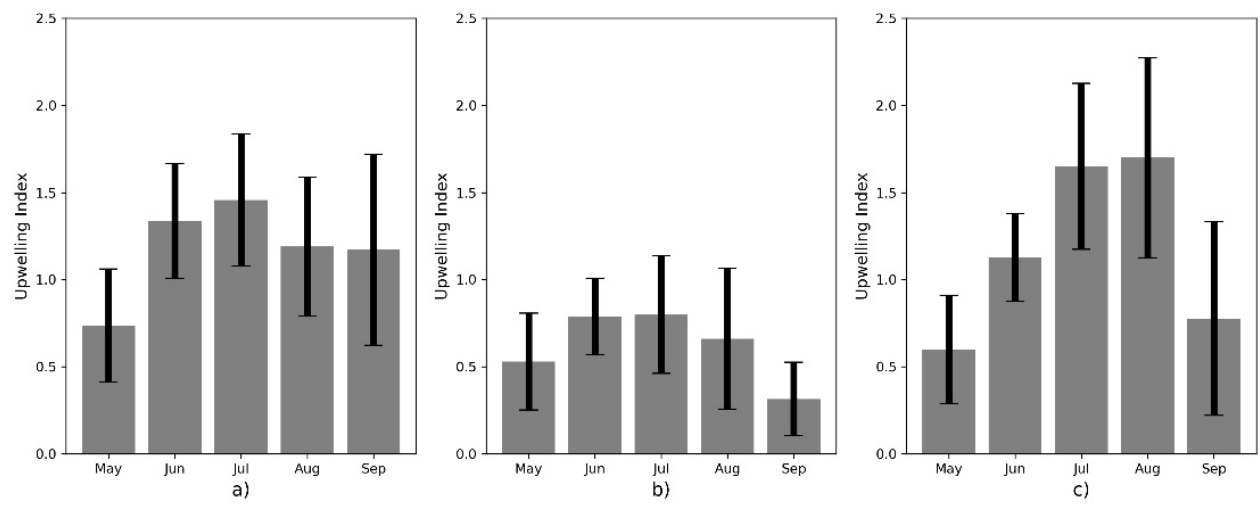

Figure 15. Monthly mean wind-driven upwelling index; (a) north, (b) central, (c) south. The error bars indicate $95 \%$ confidence intervals.

The time-series of this study is not sufficient to examine the interannual variability of the upwelling characteristics. According to the Ocean Niño Index, in the summer of 2016, the strong El Niño condition was quickly transitioned into the La Niña condition. This might have something to do with the strongest upwelling activities detected in the summer season of 2016 measured by the upwelling area (Figure 11a). In contrast, weak El Niño conditions during late spring and early summer of 2019 might have contributed to the weakest upwelling activities in the summer season of 2019 (Figure 11a). Similar ENSO influence on the upwelling of the Taiwan Strait has been documented in previous studies [3].

The role of the Kuroshio Current in the summer coastal upwelling east of Taiwan remains unclear. The incursion of the Kuroshio Current to the East China Sea plays an important role in the upwelling off Northeastern Taiwan [7-10]. A similar mechanism could help form and enhance the northern upwelling center of east Taiwan. In addition, the intrusion of the Kuroshio Current into the South China Sea through the Luzon Strait may form an anticyclonic loop current off Southern Taiwan [34-37]. The influence of the Kuroshio Current to the southern upwelling center of east Taiwan, however, is likely to be limited because this loop current more likely occurs in winter [36].

\section{Conclusions}

Coastal upwelling is important for coastal ecosystems and the blue economy. This study demonstrates the advantages of using Himawari-8 SST data to monitor the daily development of upwelling events because of its reliability and high spatial $(\sim 2 \mathrm{~km})$ and temporal (10 $\mathrm{min})$ resolutions. The semi-automatic, topographic position index based image processing method is simple, intuitive, and scale-independent. The method is able to map the spatial extent of the upwelling SST signature and, as a result, to quantitatively investigate the upwelling characteristics such as the area of influence, SST anomaly, and chlorophyll- $a$ concentrations. Most importantly, this study offers the pioneering insight into the summer upwelling along the entire Taiwan east coast. The coastal upwelling east of Taiwan is believed to be driven by the southwesterly/southerly summer monsoon winds, with a similar mechanism as the coastal upwelling along the Fujian coast on the western side of the Taiwan Strait.

In summary, the key findings of this study are:

- Wind-driven upwelling occurs along the entire Taiwan east coast during the summer monsoon season;

- There are three board upwelling centers along the Taiwan east coast: north, central, and south; 
- The upwelling around the northern center has the longest upwelling season, lasting from May to September;

- The upwelling extents are larger between June and August during the height of the summer monsoon.

Author Contributions: Conceptualization, Z.H. and J.H.; methodology, Z.H. and W.S.; writingoriginal draft preparation, Z.H.; writing-review and editing, J.H. and Z.H. All authors have read and agreed to the published version of the manuscript.

Funding: This study was jointly supported by the National Natural Science Foundation of China (91958203, 41776027 and 41730533). Z.H.'s visit to Xiamen University was supported by the MEL Visiting Fellowship (MELRS1767).

Data Availability Statement: The datasets for this research are publicly available. The wind data are provided by National Centers for Environmental Information, NOAA via https:/ /www.ncdc. noaa.gov/data-access/model-data/model-datasets/climate-forecast-system-version2-cfsv2. The Himawari-8 SST and chlorophyll- $a$ data are provided by GHRSST and JAXA/EORC via https: //www.eorc.jaxa.jp/ptree/index.html. We appreciate the use of these publically available datasets.

Acknowledgments: We would like to thank the three anonymous reviewers whose constructive comments have significantly improved the manuscript.

Conflicts of Interest: The authors declare no conflict of interest. The funders had no role in the design of the study; in the collection, analyses, or interpretation of data; in the writing of the manuscript, or in the decision to publish the results.

\section{References}

1. McGregor, H.V.; Dima, M.; Fischer, H.W.; Mulitza, S. Rapid 20th-century increase in coastal upwelling off Northwest Africa. Science 2007, 315, 637-639. [CrossRef] [PubMed]

2. Wang, D.; Gouhier, T.C.; Menge, B.A.; Ganguly, A.R. Intensification and spatial homogenization of coastal upwelling under climate change. Nature 2015, 518, 390-394. [CrossRef] [PubMed]

3. Hu, J.; Wang, X.H. Progress on upwelling studies in the China seas. Rev. Geophys. 2016, 54, 653-673. [CrossRef]

4. Huang, Z.; Wang, X.H. Mapping the spatial and temporal variability of the upwelling systems of the Australian southeastern coast using 14-year of MODIS data. Remote Sens. Environ. 2019, 227, 90-109. [CrossRef]

5. Kampf, J.; Doubell, M.; Griffin, D.; Matthews, R.L.; Ward, T.M. Evidence of a large seasonal coastal upwelling system along the southern shelf of Australia. Geophys. Res. Lett. 2004, 31, L09310. [CrossRef]

6. Varela, R.; Alvarez, I.; Santos, F.; de Castro, M.; Gomez-Gesteira, M. Has upwelling strengthened along worldwide coasts over 1982-2010? Sci. Rep. 2015, 5, 10016. [CrossRef]

7. Chang, Y.L.; Wu, C.R.; Oey, L.Y. Bimodal behavior of the seasonal upwelling off the northeastern coast of Taiwan. J. Geophys. Res. Ocean. 2009, 114, C03027. [CrossRef]

8. Chang, Y.L.; Oey, L.Y.; Wu, C.R.; Lu, H.F. Why are there upwelling on the northern shelf of Taiwan under northeasterly winds? J. Phys. Oceanogr. 2010, 40, 1405-1417. [CrossRef]

9. Chung, H.W.; Liu, C.C. Spatiotemporal variation of cold eddies in the upwelling zone off Northeastern Taiwan revealed by the Geostationary satellite imagery of ocean color and sea surface temperature. Sustainability 2019, 11, 6979. [CrossRef]

10. Yin, W.; Huang, D. Short-term variations in the surface upwelling off Northeastern Taiwan observed via satellite data. J. Geophys. Res. Ocean. 2019, 124, 939-954. [CrossRef]

11. Lyu, K.W.; Hu, J.Y.; Yang, X.Y. Spatial patterns in seasonal variability of sea surface wind over the South China Sea and its adjacent ocean. J. Trop. Oceanogr. 2012, 31, 41-47. (In Chinese with English Abstract)

12. Hu, J.; Kawamura, H.; Hong, H.; Pan, W. A review of research on the upwelling in the Taiwan Strait. Bull. Mar. Sci. 2003, 73, 605-628.

13. Jiang, Y.; Chai, F.; Wan, Z.; Zhang, X.; Hong, H. Characteristics and mechanisms of the upwelling in the southern Taiwan Strait: A three-dimensional numerical model study. J. Oceanogr. 2011, 67, 699-708. [CrossRef]

14. Chao, S.Y. Circulation of the East China Sea, a numerical study. J. Oceanogr. 1991, 42, 273-295.

15. McClatchie, S.; Middleton, J.F.; Ward, T.M. Water mass analysis and alongshore variation in upwelling intensity in the eastern Great Australian Bight. J. Geophys. Res. Ocean. 2006, 111, C08007. [CrossRef]

16. Roughan, M.; Middleton, J.H. A comparison of observed upwelling mechanisms off the east coast of Australia. Cont. Shelf Res. 2002, 22, 2551-2572. [CrossRef]

17. Bessho, K.; Date, K.; Hayashi, M.; Ikeda, A.; Imai, T.; Inoue, H.; Kumagai, Y.; Miyakawa, T.; Murata, H.; Ohno, T.; et al. An introduction to Himawari-8/9-Japan's new-generation geostationary meteorological satellites. J. Meteorol. Soc. Jpn. Ser. II 2016, 94, 151-183. 
18. Kurihara, Y.; Murakami, H.; Kachi, M. Sea surface temperature from the new Japanese geostationary meteorological Himawari-8 satellite. Geophys. Res. Lett. 2016, 43, 1234-1240. [CrossRef]

19. Hu, J.; Kawamura, H.; Li, C.; Hong, H.; Jiang, Y. Review on current and seawater volume transport through the Taiwan Strait. J. Oceanogr. 2010, 66, 591-610. [CrossRef]

20. Li, G.; Wan, R.; Li, B.; Wei, X.; Tang, J. Using remote sensing for study of temperature and salinity of surface sea water surrounding Taiwan. Mar. Geol. Front. 2017, 33, 41-46. (In Chinese with English Abstract)

21. Saha, S.; Moorthi, S.; Wu, X.; Wang, J.; Nadiga, S.; Tripp, P.; Behringer, D.; Hou, Y.T.; Chuang, H.Y.; Iredell, M.; et al. The NCEP Climate Forecast System Version 2. J. Clim. 2014, 27, 2185-2208. [CrossRef]

22. Toba, Y.; Iida, N.; Kawamura, H.; Ebuchi, N.; Jones, I.S.F. Wave dependence of sea surface wind stress. J. Phys. Oceanogr. 1990, 20, 705-721. [CrossRef]

23. Dabuleviciene, T.; Kozlov, I.; Vaiciute, D.; Dailidiene, I. Remote sensing of coastal upwelling in the south-eastern Baltic Sea: Statistical properties and implications for the coastal environment. Remote Sens. 2018, 10, 1752. [CrossRef]

24. Gill, P.C.; Morrice, M.G.; Page, B.; Pirzl, R.; Levings, A.H.; Coyne, M. Blue whale habitat selection and within-season distribution in a regional upwelling system off southern Australia. Mar. Ecol. Prog. Ser. 2011, 421, 243-263. [CrossRef]

25. Oke, P.R.; Griffin, D. The cold-core eddy and strong upwelling off the coast of New South Wales in early 2007. Deep-Sea Res. II 2011, 58, 574-591. [CrossRef]

26. Oke, P.R.; Middleton, J.H. Nutrient enrichment off Port Stephens: The role of the East Australian Current. Cont. Shelf Res. 2001, 21, 587-606. [CrossRef]

27. Roughan, M.; Oke, P.R.; Middleton, J.F. A modelling study of the climatological current field and the trajectories of upwelled particles in the east Australian current. J. Phys. Oceanogr. 2003, 33, 2551-2564. [CrossRef]

28. Willis, J.; Hobday, A.J. Influence of upwelling on movement of southern bluefin tuna (Thunnus maccoyii) in the Great Australian Bight. Mar. Freshw. Res. 2007, 58, 699-708. [CrossRef]

29. Weiss, A.D. Topographic Position and Landforms Analysis. In Proceedings of the ESRI International User Conference, San Diego, CA, USA, 9-13 July 2001.

30. Huang, Z.; Feng, M. Remotely sensed spatial and temporal variability of the Leeuwin Current using MODIS data. Remote Sens. Environ. 2015, 166, 214-232. [CrossRef]

31. Xie, S.; Huang, Z.; Wang, X. Quantitative mapping of the East Australian Current encroachment using time series Himawari-8 sea surface temperature data. J. Geophys. Res. Ocean. 2020, 125, e2019JC015647. [CrossRef]

32. Murakami, H. Ocean color estimation by Himawari-8/AHI. In Proceedings of the SPIE 9878, Remote Sensing of the Oceans and Inland Waters: Techniques, Applications, and Challenges, New Delhi, India, 4-7 April 2016; Curran Associates, Inc.: Red Hook, NY, USA, 2016; p. 987810.

33. Zhang, W.Z.; Wang, H.; Chai, F.; Qiu, G. Physical drivers of chlorophyll variability in the open South China Sea. J. Geophys. Res. Ocean. 2016, 121, 7123-7140. [CrossRef]

34. Caruso, M.J.; Gawarkiewicz, G.G.; Beardsley, R.C. Interannual variability of the Kuroshio intrusion in the South China Sea. J. Oceanogr. 2006, 62, 559-575. [CrossRef]

35. Hu, J.; Kawamura, H.; Hong, H.; Qi, Y. A review on the currents in the South China Sea: Seasonal circulation, South China Sea Warm Current and Kuroshio intrusion. J. Oceanogr. 2000, 56, 607-624. [CrossRef]

36. Nan, F.; Xue, H.; Yu, F. Kuroshio intrusion into the South China Sea: A review. Prog. Oceanogr. 2015, 137, 314-333. [CrossRef]

37. Xue, H.; Chai, F.; Pettigrew, N.; Xu, D.; Shi, M.; Xu, J. Kuroshio intrusion and the circulation in the South China Sea. J. Geophys. Res. Ocean. 2004, 109, C02017. [CrossRef] 